\title{
COMMENT
}

\section{"JOIN THE SIERRA CLUB!": IMPOSITION OF IDEOLOGY AS A CONDITION OF PROBATION}

\author{
JAIMY M. LEVINE† \\ INTRODUCTION
}

Donald J. Bohnert was an entrepreneur who created a business out of accepting hazardous waste for storage and disposal. The problem, however, was that Bohnert did not possess the appropriate permits to do this as required by Ohio's hazardous waste laws. Indeed, Bohnert never disposed of the waste he accepted; he transported it to rented storage lockers where it remained. ${ }^{1}$ That is, until the local environmental agency discovered Bohnert's activities. Imagine Bohnert's emotions as the state attorney general's office instituted a criminal enforcement action against him, as he pleaded guilty, and as he was convicted of 207 counts of the illegal transportation, disposal, and storage of hazardous waste. ${ }^{2}$ Whatever these emotions, however, imagine Bohnert's surprise on learning that to avoid serving two years in prison, he must for five years be a member of the Sierra Club, ${ }^{3}$ a national environmental

† A.B. 1991, Washington University; J.D. Candidate 1995, University of Pennsylvania. In memory of my father, Gerald M. Levine, who taught me to strive for the best without sacrificing my ideals of right and wrong. With love and respect, I dedicate this Comment to my mother, Sharon P. Levine, who has shown me how to make my own tomorrows and to rise to each occasion, and to my sisters, Robin and Leslie, whose constant support sustains and anchors me. I am also grateful to my colleagues on the Law Review for their helpful comments and editorial assistance.

1 Telephone Interview with J. Michael Marous, Assistant Chief and Director of Criminal Prosecutions, Environmental Enforcement, Ohio Attorney General's Office (Apr. 13, 1994); Telephone Interview with Michael Walton, attorney for Donald J. Bohnert, Cincinnati, Ohio (Apr. 14, 1994).

${ }^{2}$ See Ohio v. Bohnert, No. B91-2520 (C.P. Hamilton County, Ohio Nov. 6, 1991) (court's judgment setting out counts of conviction). Bohnert was convicted on a total of 219 counts, including the illegal transportation, disposal, and storage of hazardous waste; falsification of hazardous waste manifests; illegal operation of a hazardous waste facility; forgery; and criminal endangering. See id.

${ }^{3}$ Bohnert was sentenced to serve a total of eight years in prison. See id. Upon his release from prison, an additional two-year prison sentence was to be suspended and Bohnert would be placed on probation on the condition that, among other things, he "become a member in good standing of the environmental group known as Sierra 
advocacy organization that promotes environmental preservation through a broad political agenda that includes lobbying and litigating. ${ }^{4}$ Despite Bohnert's dismay at being forced to join a group whose views he does not support and whose views are not accepted by the mainstream of our society, ${ }^{5}$ Bohnert submits to his required membership to avoid the alternative of prison life, the resulting loss of liberty, and the associated stigma. ${ }^{6}$

Bohnert has not been the only person faced with such a choice. Recently, several judges have sentenced people convicted of environmental crimes to serve time in the local Sierra Club. ${ }^{7}$ Such "creative sentencing" aims to (1) promote rehabilitation of the offender, (2) ensure public safety by placing the offender under the continued supervision of law enforcement, and (3) minimize costs to the community by avoiding the expense associated with incarceration. ${ }^{8}$ While creative sentences should be encouraged in light of

Club." Id.

'For a discussion of the Sierra Club's history, goals, and activities, see infra notes $237-44$ and accompanying text.

${ }^{5}$ See infra notes 261-62 and accompanying text.

${ }^{6}$ Bohnert never appealed his sentence.

${ }^{7}$ See Cruel and Unusual Punishment, INC., Apr. 1993, at 9 (describing a case in which the owner of an electroplating company pleaded guilty to violations of state hazardous waste laws and was placed on probation on the condition that he become a member in good standing of the Sierra Club); Environmental Enforcement Section, Attorney General of Ohio, Summary of Environmental Crime Convictions (Apr. 15, 1994) (on file with author) (listing four defendants other than Bohnert who were sentenced to join the Sierra Club between 1991 and February 1994). Some courts have also required defendants convicted of environmental violations to contribute money to environmental and conservation groups. See Edward Felsenthal, Environmental Sentences Upset Some Lawyers, WALL Sr. J., Sept. 7, 1993, at B1 (noting that courts in California have required defendants to make cash contributions to environmental groups); Hunting Guide Sentenced, THE STAR-DEMOCRAT (Easton, Md.), Aug. 27, 1993, at 5A (describing a case in which two defendants who pleaded guilty to hunting charges were required as a condition of probation to donate $\$ 50$ each to the National Wildlife Federation, a conservation organization).

${ }^{8}$ For examples of other creative sentences and the resulting public controversy, see Robin Abcarian, "Apology Ads" Raise Issue of Fair Play: Punishment-Citing Ethical Questions, Some Newspapers Refuse to Publish Court-Ordered Advertisements Designed to Embarrass Defendants, L.A. TIMES, Feb. 4, 1991, at E1 (describing the controversy within the newspaper industry over how to react to creative sentences that require offenders to take out ads exposing their crimes in local papers); Mark Curriden, Making Punishment Fit Crime Often Nol Popular, ATLANTA J. \& Const., Jan. 9, 1992, at A3, available in LEXIS, Nexis Library, ATLJNL File (outlining the public controversy over creative sentencing and giving many noteworthy examples); George Frank, Graffiti Cleanup Is Possible Punishment, L.A. TIMES, Apr. 12, 1990, at B2, available in LEXIS, Nexis Library, LAT File (reporting that county judges might soon use a "proposed graffiti abatement program" as a form of alternative sentencing); Making the Punishment Fit the Crime, CHI. TRIB., May 28, 1992, at 24 (editorial 
the current crisis in prison capacity, ${ }^{9}$ sentencing discretion that allows a judge to compel membership in a political advocacy organization has strayed too far.

Creative sentences stem from a court's statutory authority to place a convicted criminal ${ }^{10}$ on probation in lieu of incarceration. ${ }^{11}$ Authorizing statutes, ${ }^{12}$ however, place few restrictions on probation and thus offer little guidance to a judge in determining who should be granted probation, the length of the probation term, and the particular conditions of an offender's probation. ${ }^{13}$ These

advocating creative alternatives that "send a lasting message to the offenders and stop the behavior"); Moderm Day "Scarlet Letter" Thief to Wear TShirt Proclaiming Her Crime, SAN Diego UNION-TRIB., July 11, 1992, at B-14 (criticizing creative sentences that "deliberately seek to degrade and humiliate the offender"), available in LEXIS, Nexis Library, CURNWS File.

${ }^{9}$ There are more prisoners in the United States today than at any time in our history. The combined federal and state prison population reached a record high of 789,347 at the end of 1991. See U.S. BUREAU OF THE CENSUS, U.S. DEP'T OF COMMERCE, Statistical ABSTRACT OF THE UNITEd STATES 210 (113th ed. 1993). At the end of 1980, the prison population numbered 315,974, less than half of the 1991 figure. See id. By 1987, 46 states and the Federal Bureau of Prisons reported serious crowding problems. See Jeff Bleich, Comment, The Politics of Prison Crowding, 77 CALIF. L. REV. 1125, 1125-26 \& n.3 (1989) (citing BUREAU OF JUSTICE STATISTICS, U.S. DEP'T OF JUSTICE, PRISONERS IN 1987, at 5 (1988)). As a result of these trends, by January $1,1992,66 \%$ of the country's "jurisdictions had their . . prison . . systems under court order or consent decree to alleviate overcrowded prison conditions." Russell W. Gray, Note, Wilson v. Seiter: Defining the Components of and Proposing a Direction for Eighth Amendment Prison Condition Law, 41 AM. U. L. REV. 1339, 1340 \& n.6 (1992) (citing National Prison Project, American Civil Liberties Union FOUND., STATUS REPORT: STATE PRISONS AND THE COURTS (1992)). This prison crisis has resulted in an increased need for alternatives to traditional prison sentences. See Nancy Blodgett, Altemative Sentencing: Overcrowded Prisons Prompt New Responses, A.B.A. J., Nov. 1, 1987, at 32 (describing the prison overcrowding crisis and how it has prompted criminal justice specialists to pursue alternatives to prison, including expanded probation systems); Francis X. Clines, Prisons Run Out of Cells, Money and Choices, N.Y. TIMES, May 28, 1993, at B7 (same).

${ }^{10}$ Although corporate offenders are proper subjects of probation, see 18 U.S.C. § 3551(c)(1) (1988); United States v. Atlantic Richfield Co., 465 F.2d 58, 61 (7th Cir. 1972), this Comment will focus on the probation of individual offenders.

11 "Creativity" has similarly been employed in other stages of the criminal proceeding. For example, as part of a plea agreement, an Assistant U.S. Attorney required 14 members of the Fourth Reich Skinheads to complete an education program designed specifically to "enlighten and frighten" and to "confront the causes and consequences of racism." Jim Newton, Skinheads Get Crash Course in Tolerance, STAR TRIB. (Minneapolis), Jan. 1, 1994, at 5A. The program, dubbed "Operation Grow Hair," included a visit to a jail, a meeting with black U.S. District Judge Terry Hatter, a viewing of Schindler's List, and a meeting with Holocaust survivors. See id.

${ }^{12}$ For a discussion of the statutory authority of probation, see infra notes 36-42 and accompanying text.

${ }^{15}$ See 3 StANDARDS For CRIMINAL Justice Std. $18-2.3 \mathrm{cmt}$, at 89 (American Bar 
statutes reflect the theory that because sentencing judges are often close to the particulars of each offender's background, they should be given discretion in granting probation and setting the terms and conditions of probation that best rehabilitate offenders and provide adequate public protection. ${ }^{14}$

Common conditions of probation include the payment of a fine, restitution to the victim of the offense, completion of a drug or alcohol treatment program, and maintenance of a satisfactory job. ${ }^{15}$ Sentencing courts often attempt to make the punishment fit the crime. As creative conditions of probation, courts have prohibited women convicted of child abuse from becoming pregnant, ${ }^{16}$ prohibited an offender convicted of pirating cable

Ass'n 1980) [hereinafter ABA SENTENCING STANDARDS] ("It has been said that legislative limitations on probation conditions are 'conspicuously absent' ...." (citation omitted)).

${ }^{14}$ See id. Std. 18-2.3(d) "The sentencing court should be authorized to individualize the conditions of probation to fit the circumstances of each case."); see also HARRY E. Allen et Al., Probation AND PAROle in AMErica 82 (1985) (noting that "granting probation is a highly individualized process that usually focuses on the criminal rather than the crime").

${ }^{15}$ See ABA SENTENCING STANDARDS, supra note 13, Std. 18-2.3(f). The ABA Sentencing Standards state that probation conditions may appropriately deal with the following matters:

(i) cooperating with a program of supervision;

(ii) meeting family responsibilities;

(iii) maintaining steady employment or engaging in a specific employment or occupation;

(iv) pursuing prescribed educational or vocational training;

(v) undergoing available medical or psychiatric treatment, which treatment may include periodic testing for narcotics use;

(vi) maintaining residence in a prescribed area or in a special facility established for or available to persons on probation;

(vii) refraining from consorting with specified types of people, frequenting specified types of places, or engaging in specified business, employment, or professional activities, to the extent that such restrictions have a reasonable relationship with the prior offense or anticipatable future criminal behavior;

(viii) making restitution of the fruits of the crime or reparation for loss or damage caused thereby;

(ix) refraining from the use of alcohol or illegal drugs or the possession of dangerous weapons; and

(x) requiring a term of community service, such as in a hospital or other public or charitable facility.

Id.

${ }^{16}$ See Contraceptive Implant Is Substitute for Jail, N.Y. Times, Feb. 18, 1994, at A17 (describing how a "mildly retarded woman" convicted of child abuse avoided a jail term by agreeing to a contraceptive implant as a condition of probation); Judge Orders Birth Control for Abusive Mother, L.A. TIMES, Jan. 30, 1991, at B6 (listing reader 
television services from watching cable television, ${ }^{17}$ required driving under the influence offenders to participate in confrontation sessions with victims of drunk driving accidents, ${ }^{18}$ allowed burglary victims to go into the burglars' homes and take anything they wanted, ${ }^{19}$ and required a landlord convicted of building code violations to live alongside his tenants. ${ }^{20}$

Conditioning a probation on membership in an environmental advocacy organization such as the Sierra Club infringes on the First Amendment ${ }^{21}$ right to be free from compelled speech. ${ }^{22}$ The U.S. Supreme Court has recognized that the First Amendment protects the rights to "refrain from speaking"23 and to be "intellectually and spiritually diverse or even contrary." 24 By imposing an ideology as a condition of probation, the sentencing court implicates this fundamental First Amendment right.

It is widely recognized, however, that a condition of probation is not improper merely because it infringes a fundamental right. ${ }^{25}$

reactions to a probation condition that required the defendant, who was convicted of child abuse, to use Norplant, a surgically implanted contraceptive device, for the entire five-year probationary term in the case of People v. Johnson, No. 29,390 (Super. Ct. Tulare County, Cal. Jan. 2, 1991)). See generally Stacey L. Arthur, The Norplant Prescription: Birth Control, Woman Controb or Crime Control?, 40 UCLA L. REv. 1 (1992). In many of these cases, however, conditions forbidding pregnancy have been overturned on appeal. See, e.g., People v. Pointer, 199 Cal. Rptr. 357, 364-66 (Ct. App. 1984) (holding that a condition of probation prohibiting defendant from becoming pregnant was reasonably related to preventing future criminality, but invalid because other less restrictive alternatives were available); Rodriguez v. State, 378 So. 2d 7, 8, 10 (Fla. Dist. Ct. App. 1979) (holding invalid a probation condition that prohibited pregnancy because the condition "add[s] nothing to decrease the possibility of further child abuse or other criminality"); State v. Mosburg, 768 P.2d 313, 315 (Kan. Ct. App. 1989) (holding that a probation condition prohibiting defendant from becoming pregnant violated the defendant's right to privacy).

${ }^{17}$ See Unusually Creative Judges Now Believe Some Punishments Can Fit the Times, CHI. TRIB., July 3, 1988, at $\mathrm{Cl}$.

${ }^{18}$ See Making the Punishment Fit the Crime, supra note 8, at 24.

${ }^{19}$ See Red, Crime Doesn't Pay-It Costs, ORLANDo SENTINEL TRIB., July 2, 1992, at A18, available in LEXIS, Nexis Library, CURNWS File.

${ }^{20}$ See Instead of Jail: "Welcome, Reptile!," N.Y. TimES, Feb. 17, 1988, at A22.

${ }^{21}$ U.S. CONST. amend. I. The First Amendment provides that "Congress shall make no law respecting an establishment of religion, or prohibiting the free exercise thereof; or abridging the freedom of speech, or of the press; or the right of the people peaceably to assemble, and to petition the Government for a redress of grievances." Id.

${ }^{22}$ See infra notes 225-53 and accompanying text (discussing the right to be free from compelled expression).

${ }^{23}$ Wooley v. Maynard, 430 U.S. 705, 714 (1977).

${ }^{24}$ West Virginia State Bd. of Educ. v. Barnette, 319 U.S. 624, 641 (1943).

${ }^{25}$ See 3 Wayne R. Lafave \& Jerold H. ISRael, Criminal Procedure $\$ 25.3$, at 
To promote rehabilitation while securing public safety, conditions of probation necessarily restrict a probationer's liberty. ${ }^{26}$ Even the most basic condition of probation, that the offender refrain from further law-breaking activity during the probation term, ${ }^{27}$ limits the probationer's liberty. If a probationer violates a condition of her probation by violating a collateral law, the probationer risks greater consequences than the nonprobationer. The probationer can be prosecuted for the collateral crime in the same way as the nonprobationer, but in addition, the court can revoke the offender's probation, in which case incarceration for the first conviction might be appropriate. Nevertheless, rehabilitation of the offender, public safety, and facilitation of law enforcement justify the imposition of this probation condition.

Whereas probation conditions that infringe fundamental rights are permissible because they directly relate to the purposes of probation, probation conditions that infringe on the First Amendment right to be free from compelled speech and association are not directly related to the purposes of probation. Presumably, education in the scope and application of environmental laws would facilitate both rehabilitation of an offender of environmental laws and protection of the public by giving the offender the tools to comply with these laws in the future. Yet the Sierra Club's agenda includes changing the current scope and implementation of environmental laws. ${ }^{28}$ Imposing such an ideology on a probationer is unnecessary to rehabilitate the offender and assure future compliance with the law.

Moreover, the exercise of First Amendment liberty interests is essential to the successful rehabilitation of a probationer. Histori-

146-52 (1984 \& Supp. 1991); 2 Charles A. Wright, Federal Practice ANd Procedure § 529, at 146-57 (1982 \& Supp. 1993); see also infra notes 105-16 and accompanying text.

${ }^{26}$ See Higdon v. United States, 627 F.2d 893, 898 (9th Cir. 1980) ("The fact that conditions restrict [the probationer's] freedom is not dispositive-virtually all probation conditions are restrictive."); see also United States v. Consuelo-Gonzalez, 521 F.2d 259, 266 (9th Cir. 1975) ("It is our belief that reasonable restraints on probationers are necessary to promote the use of probation as an alternative to incarceration."); ABA SENTENCING STANDARDS, supra note 13, Std. 18-2.3 cmt., at 87 ("Inherently, probation conditions involve the regulation of liberty ....").

${ }^{27}$ Under the federal Sentencing Reform Act, which governs crimes committed after November 1, 1987, the requirement that all federal offenders not commit another federal, state, or local crime during the period of probation is a mandatory condition of probation. See 18 U.S.C. \$ 3563(a)(1) (1988).

${ }^{28}$ For a discussion of the Sierra Club's history, goals, and activities, see infra notes 237-44, 262 and accompanying text. 
cally, First Amendment rights have been accorded "preferred status $^{\text {299 }}$ for several reasons. First, freedom of expression guarantees that the marketplace of ideas will ultimately reveal the truth. ${ }^{30}$ Second, free speech is essential to "intelligent self-government in a democratic system. ${ }^{31}$ Most important for the purposes of probation, freedom of expression promotes self-fulfillment, autonomy, and human dignity. ${ }^{32}$ Respect for the structure of society begins with self-respect, and a probationer who is unnecessarily deprived of the chance to develop a sense of autonomy, and a sense of dignity for self and human life will be unable to transform those values into respect for society's legal order. ${ }^{33}$ Furthermore, the probationer will perceive the unnecessary deprivation of her rights as indicative of the unfairness of the legal system; in turn, the

${ }^{29}$ Gerald Gunther, Constrtutional LAw $1105-17$ (10th ed. 1980); see also NeIL P. Cohen \& James J. Gobert, The Law of Probation and PAROle § 5.10, at 213 (1983 \& Supp. 1993) (noting that, in general, conditions of probation infringing on First Amendment rights are evaluated especially critically because of the preferred nature of these rights).

${ }^{30}$ See Abrams v. United States, 250 U.S. 616 (1919) (Holmes, J., dissenting):

[W] hen men have realized that time has upset many fighting faiths, they may come to believe even more than they believe the very foundations of their own conduct that the ultimate good desired is better reached by free trade in ideas-that the best test of truth is the power of the thought to get itself accepted in the competition of the market, and that truth is the only ground upon which their wishes safely can be carried out.

Id. at 630. For criticism of the marketplace of ideas theory, see C. Edwin Baker, Scope of First Amendment Freedom of Speech, 25 UCLA L. REV. 964, 974 (1978) ("The assumptions on which the classic marketplace of ideas theory rests are almost universally rejected today. Because of this failure of assumptions, the hope that the marketplace leads to truth, or even to the best or most desirable decision, becomes implausible."); Stanley Ingber, The Marketplace of Ideas: A Legitimizing Myth, 1984 DUKE L.J. 1, 4-5 (arguing that the marketplace of ideas often justifies government intervention and regulation of expression).

${ }^{31}$ LAURENCE H. TRIBE, AMERICAN CONSTITUTIONAL LAW \$ 12-1, at 786 (2d ed. 1988) (ascribing this theory to Alexander Meiklejohn). For criticism of the intelligent self-government theory, see Martin H. Redish, The Value of Free Speech, 130 U. PA. L. REv. 591, 601 (1982) (arguing that this theory of the First Amendment is too narrow, and that "[i]ndeed, political democracy is merely a means to-or, in another sense, a logical outgrowth of-the much broader [First Amendment] value of individual selfrealization").

32 See David Richards, Free Speech and Obscenity Law: Toward a Moral Theory of the First Amendment, 123 U. PA. L. REV. 45, 62 (1974) ("The value of free expression ... rests on its deep relation to self-respect arising from autonomous self-determination without which the life of the spirit is meager and slavish."). For criticism of this theory, see Robert H. Bork, Neutral Principles and Some First Amendment Problems, 47 IND. L.J. 1, 25 (1971).

ss See infra notes 100-04 and accompanying text. 
probationer will be less inclined to respect and abide by society's legal structure in the future.

The recent proliferation of probation conditions that require an offender to associate with a particular ideology ${ }^{34}$ compels an examination into the doctrines currently employed by courts reviewing probation conditions that infringe fundamental rights. While the Supreme Court has failed to articulate any standard by which such conditions should be measured, lower courts have been forced to develop their own doctrines to address this issue. Without coherent guidance, however, courts have defined several different standards, none of which have been applied with any certainty or regularity. ${ }^{35}$ As sentencing judges continue to respond to the mounting prison crisis, the practice of alternative sentencing becomes more frequent, and as a result this lack of clear guidance becomes increasingly significant in affecting fundamental rights.

Part I of this Comment reviews the history, underlying authority, and conditions of probation in general. The basic standard of review applied to probation conditions is then construed. Part II surveys conditions of probation that restrict a probationer from engaging in constitutionally protected activity and the limits on imposing such conditions. This Part reveals the current lack of coherence among and within jurisdictions and the resulting inadequate protection accorded fundamental First Amendment rights.

Part III of this Comment analyzes conditions that infringe a probationer's First Amendment right to be free from compelled expression. This Part reveals that such probation conditions are only indirectly related to the purposes of probation, and that they in fact deprive the probationer of the opportunity for meaningful rehabilitation because they deny the probationer the right to develop self-respect, autonomy, and human dignity. This Part then proposes that probation conditions that impose an ideology merit a heightened constitutional scrutiny. Only when there are no less

${ }^{34}$ See infra notes $191-213$ and accompanying text.

${ }^{35}$ For one commentator's explanation for this phenomenon, see Heinz R. Hink, The Application of Constitutional Standards of Protection to Probation, 29 U. CHI. L. REV. 483,484 (1962) ("The wide range of trial court discretion in matters of ... probation ... has found appellate courts highly unwilling to establish definite criteria for the use of trial judges."). For a discussion of the reasonableness standard, the balancing standard, and the least restrictive alternative standard, see infra notes 117-70 and accompanying text. 
restrictive alternatives should an offender's probation be conditioned on an affirmative requirement that compels expression.

\section{Probation ANd Conditions in General}

\section{A. Authority and Purposes of Probation}

The power to grant probation is purely statutory. ${ }^{36}$ Both federal ${ }^{37}$ and state $^{38}$ jurisdictions have enacted statutes authorizing probation. Under the Federal Probation Act, ${ }^{39}$ in force for crimes committed prior to November 1, 1987, probation is authorized upon suspension of a sentence. ${ }^{40}$ The court is authorized to condition probation "upon such terms and conditions as the court deems best." ${ }^{11}$ The Act expressly provides as conditions of probation the payment of a fine, restitution to aggrieved parties, and support for legal dependents. ${ }^{42}$

${ }^{36}$ Courts have no inherent power to grant probation. See Ex parte United States, 242 U.S. 27, 52 (1916) (concluding that "recourse must be had to Congress whose legislative power on the subject is in the very nature of things adequately complete"); see also FED. R. CRM. P. 32(e) ("After conviction of an offense not punishable by death or by life imprisonment, the defendant may be placed on probation if permitted by law."). In response to Ex parte United States, Congress enacted the Federal Probation Act in 1925. See Act of Mar. 4, 1925, ch. 521, 43 Stat. 1259, 125961 (codified as amended at 18 U.S.C. $\$ \S 3651-3656$ (1988) (repealed Nov. 1, 1987)).

${ }^{37}$ See Sentencing Reform Act, Pub. L. No. 98-473, 98 Stat. 1987 (1984) (codified as amended at 18 U.S.C. $\$ \S 3551-3559,3561-3566,3571-3574,3581-3586$ (1988), and 28 U.S.C. $\$ \S 991-998$ (1988) (effective Nov. 1, 1987)). For crimes committed prior to November 1, 1987, the Federal Probation Act, see 18 U.S.C. $\$ \$ 3651-3656$, authorizes probation.

${ }^{38}$ See COHEN \& GOBERT, supra note $29, \S 5.03$ (listing state statutes that authorize probation); Arthur, supra note 16, at 29 n.166 (same); Jeffrey C. Filcik, Recent Development, Signs of the Times: Scarlet Letter Probation Conditions, 37 WASH. U. J. URB. \& CONTEMP. L. 291, 294 n.11 (1990) (same).

${ }^{39}$ Act of Mar. 4, 1925, ch. 521, 43 Stat. 1259, 1259-61 (codified as amended at 18 U.S.C. $§ \S 3651-3656$ (1988) (repealed Nov. 1, 1987)).

${ }^{40}$ See id. $\$ 3651$. The relevant portions of the statute state:

Upon entering a judgment of conviction of any offense not punishable by death or life imprisonment, any court having jurisdiction to try offenses against the United States when satisfied that the ends of justice and the best interest of the public as well as the defendant will be served thereby, may suspend the imposition or execution of sentence and place the defendant on probation for such period and upon such terms and conditions as the court deems best.

Id.

\footnotetext{
${ }^{11} I d$.

12 See id.
} 
Courts have further relied on the permissive language in the Federal Probation Act to impose a wide variety of conditions on probation that are not expressly provided in the Act. ${ }^{43}$ These discretionary conditions include, for example, a requirement that the probationer abide by all applicable laws, ${ }^{44}$ a requirement that the offender not associate with any known homosexuals, ${ }^{45}$ a requirement that the offender register with the Selective Service, ${ }^{46}$ and a requirement that the offender not associate with any Irish Catholic organizations. ${ }^{47}$ Courts have also imposed a variety of discretionary probation conditions under state probation statutes. ${ }^{48}$

The primary purpose of probation is rehabilitation. ${ }^{49}$ Proba-

${ }^{43}$ See United States v. Tonry, 605 F.2d 144, 147 (5th Cir. 1979) (finding the Federal Probation Act's list of probation conditions not to be exclusive); see also Mary Lou Howard, Note, Charitable Contributions as a Condition of Federal Probation for Corporate Defendants: A Controversial Sanction Under New Law, 60 NoTrR DAME L. REv. 530, 533-38 (1985) (outlining the debate over whether the Federal Probation Act's explicit list of conditions of probation is exemplary and therefore authorizes the sanction of charitable contributions to be given to nonaggrieved parties).

"See, e.g., ADVISORY COMM. ON SENTENCING \& REVIEW, AMERICAN BAR ASS'N, PROBATION \& 3.2(a) (1970), reprinted in STANDARDS RELATING TO THE ADMINISTRATION of Criminal Justice 398 (American Bar Ass'n 1974) [hereinafter ABA ProbATION STANDARDS] (recommending that "[i]t should be a condition of every sentence to probation that the probationer lead a law-abiding life during the period of his probation $^{n}$ ); see also 18 U.S.C. $\$ 3563(\mathrm{a})(1)$ (1988) (Sentencing Reform Act) (governing crimes committed after November 1,1987 and requiring that all federal offenders not commit another federal, state, or local crime during the period of probation).

${ }^{45}$ See United States v. Kohlberg, 472 F.2d 1189, 1190 (9th Cir. 1973) (upholding such a condition of probation for an offender who was convicted of mailing obscene matter).

${ }^{46}$ See United States v. Alarik, 439 F.2d 1349, 1351 (8th Cir. 1971) (upholding such a condition of probation for an offender convicted of refusal to register for the draft).

${ }^{17}$ See Malone v. United States, 502 F.2d 554, 556-57 (9th Cir. 1974) (upholding conditions of probation that prohibited the offender, convicted of unlawful exportation of firearms from the United States to the United Kingdom, from associating with any Irish Catholic organizations or the American Irish Republican movement, and from visiting any Irish pubs), cert. denied, 419 U.S. 1124 (1975).

${ }^{48}$ Discretionary conditions approved of under various state probation statutes include a requirement that a convicted purse snatcher wear metal taps on his shoes, see People v. McDowell, 130 Cal. Rptr. 839, 842-44 (Ct. App. 1976), a requirement that a probationer convicted of driving under the influence of alcohol affix a bumper sticker to that effect on his automobile, see Goldschmitt v. State, 490 So. 2d 123, 12526 (Fla. Dist. Ct. App. 1986), and a requirement that a probationer convicted of sexual abuse be required to post warning signs on his home and on his automobile reading "Dangerous Sex Offender," see State v. Bateman, 771 P.2d 314, 315, 319 (Or. Ct. App. 1989).

${ }^{49}$ See Roberts v. United States, 320 U.S. 264 (1943). In Roberts, the Supreme Court noted that the purpose of probation was 
tion is an opportunity for the offender to reform without the stigma or the corruptive influences of incarceration. ${ }^{50}$ These factors are particularly appropriate in cases of white-collar crime, where the perpetrator is usually found to be an otherwise productive member of society. ${ }^{51}$ Furthermore, practical considerations such as prison

to provide an individualized program offering a young or unhardened offender an opportunity to rehabilitate himself without institutional confinement under the tutelage of a probation official and under the continuing power of the court to impose institutional punishment for his original offense in the event that he abuse this opportunity.

Id. at 272; see also Higdon v. United States, 627 F.2d 893, 897 (9th Cir. 1980) ("The primary purpose of probation is to rehabilitate the offender."); Porth v. Templar, 453 F.2d 330, 333 (10th Cir. 1971) ("This court has said that the purpose of probation is to 'give the convicted person an opportunity to mend his way and to so have his freedom under conditions ....'” (quoting Thomas v. United States, 327 F.2d 795, 797 (10th Cir. 1964))). Courts generally recognize protection of the public as the other fundamental purpose of probation. See, e.g., United States v. Terrigno, 838 F.2d 371,374 (9th Cir. 1988) (noting that the "twin goals of probation" are "rehabilitation and protection of the public"); Owens v. Kelley, 681 F.2d 1362, 1366-67 (11th Cir. 1982) (noting that the "two essential purposes of probation . . . are the rehabilitation of the probationer, and the protection of society").

${ }^{50}$ See United States v. Murray, 275 U.S. 347, 357 (1928) (noting that probation works so that the "stigma might be withheld and an opportunity for reform and repentance be granted before actual imprisonment should stain the life of the convict" ); see also ABA ProBATION STANDARDS, supra note $44, \S 1.2$, at 394 . The ABA Probation Standards list the following reasons why probation is desirable:

(i) it maximizes the liberty of the individual while at the same time vindicating the authority of the law and effectively protecting the public from further violations of law;

(ii) it affirmatively promotes the rehabilitation of the offender by continuing normal community contacts;

(iii) it avoids the negative and frequently stultifying effects of confinement which often severely and unnecessarily complicate the reintegration of the offender into the community;

(iv) it greatly reduces the financial cost to the public treasury of an effective correctional system;

(v) it minimizes the impact of the conviction upon innocent dependents of the offender.

Id.; see also Edgardo Rotman, Beyond Punishment: A New View ON THE REHABILITATION OF CRIMINAL OFFENDERS 154 (1990) (noting that probation avoids the "desocializing effects of imprisonment and allow[s] the use of the existing community resources to make the offender better able to lead a law-abiding life ${ }^{n}$ ).

${ }^{51}$ See James C. Weissman, Constitutional Primer on Modern Probation Conditions, 8 NEW ENG.J. PRISON L. 367, 370 (1982) ("Public interest in punishing effectively these [white-collar] non-traditional criminals has stimulated creative sentencing practices." (footnote omitted)); see also ROTMAN, supra note 50, at 13 (noting that although they might at first seem outside the scope of meaningful rehabilitative efforts, socially welladjusted white-collar and regulatory offenders are appropriate candidates for rehabilitation). 
overcrowding and the economic burdens of incarceration support placing offenders on probation. ${ }^{52}$

Our system of trial and sentencing requires that trial judges maintain broad discretion in determining conditions of probation and setting terms of probation. The trial judge is uniquely situated to learn about each defendant and the crime of which she is convicted. ${ }^{53}$ To serve sufficiently the purposes of probation, the trial judge must be equipped with the power to craft a term of probation that is most likely to effect the probationer's rehabilitation.

Early theories characterized probation as a privilege, not a right. The "act of grace" theory suggested that probation conditions were unreviewable because the offender did not have a substantive right to probation. $^{54}$ The offender could either accept the probation conditions as granted, or chose the alternative, incarceration. ${ }^{55}$

${ }^{52}$ See ABA SENTENCING STANDARDS, supra note 13, Std. 18-2.3 cmt., at 77 (noting that "probation costs about one-fourteenth as much as imprisonment"); HowARD Abadinsky, Probation and Parole: Theory and Practice 391 (1977) ("The cost of incarceration and the current overcrowding in most prison systems would appear to limit the viability of the increased use of imprisonment . . .."); ALLEN ET AL., supra note 14, at 264 (highlighting several reasons why probation is a relatively cost effective alternative to imprisonment); ROTMAN, supra note 50, at 161 (noting that the increasing overcrowding of prisons is a "strong pragmatic motivation for favoring . . . noncustodial sanctions"); Arthur, supra note 16, at 31 (questioning whether probation has "simply become a practical necessity").

The crisis of overcrowding in prisons has caused many penal systems to implement rudimentary alternatives to traditional prisons. For example, Arizona shifted drunk driver incarcerations to tents to house more serious offenders in cells. See Clines, supra note 9, at B7. For statistics on the scope of the prison crisis, see supra note 9.

${ }^{53}$ See United States v. Stine, 675 F.2d 69, 71-72 (3d Cir.) (noting that trial judges have the "front-line responsibility for accommodating the needs of society with the needs of convicted offenders," and that the appellate court's review of probation conditions is limited "because it cannot replicate the trial judge's superior vantage point"), cert. denied, 458 U.S. 1110 (1982).

${ }^{54}$ See Escoe v. Zerbst, 295 U.S. 490, 492-93 (1935) ("Probation or suspension of sentence comes as an act of grace to one convicted of a crime, and may be coupled with such conditions in respect of its duration as Congress may impose."); United States v. Kohlberg, 472 F.2d 1189, 1190 (9th Cir. 1973) (relying on the premise that probation is an act of grace); Goldschmitt v. State, 490 So. $2 \mathrm{~d} 123,125 \mathrm{n} .2$ (Fla. Dist. Ct. App. 1986) ("[P]robation generally is but a matter of grace."); see also Note, Judicial Review of Probation Conditions, 67 CoLUM. L. REv. 181, 188-91 (1967) (discussing how the "act of grace" theory was an early obstacle to the review of probation conditions). But see ROTMAN, supra note 50, at 11-13 (advocating that due process encompasses a concept of a constitutional right to rehabilitation).

${ }^{55}$ Even today, when it is generally recognized that probationers have a right to review of probation conditions, the conditions are rarely litigated. This is due in part to the fact that most offenders are "delighted to receive probation" in light of the 
Although in 1973 the Supreme Court disavowed the "act of grace" theory, ${ }^{56}$ lower courts continue to pay it homage. ${ }^{57}$

The "contract theory" of probation characterized probation as a contractual relationship in which the court agrees to release the offender, and the offender, in return, agrees to abide by the probation conditions imposed by the court. ${ }^{58}$ The offender thereby waives any objections to the probation conditions by agreeing to accept a suspended sentence from the court. Many courts refuse to rely on this contract theory of probation ${ }^{59}$ because the probationer's bargaining power in any such contract negotiation is wholly deceptive considering that the probationer's alternative is incarceration. ${ }^{60}$

alternative of incarceration. COHEN \& GOBERT, supra note $29, \S 5.08$, at 207-08.

Similarly, lack of desire or resources on the part of the probationer to object to probation conditions has frustrated other interested parties or family members, who cannot challenge the probation conditions of third parties. See West v. Paige, $835 \mathrm{~F}$. Supp. 20, 21 (D. Me. 1993) (" [T] he right to seek relief belongs to [the defendant], not to the plaintiff. The fact that the plaintiff has a close relationship with [the defendant] as the mother of his child and as his fiancee does not give her any right to challenge the probation conditions imposed upon him and his activities.").

${ }^{56}$ See Gagnon v. Scarpelli, 411 U.S. 778, 782 n.4 (1973) ("It is clear ... that a probationer can no longer be denied due process [on the grounds that] . . probation is an 'act of grace."').

${ }^{57}$ See Bruce D. Greenberg, Probation Conditions and the First Amendment: When Reasonableness Is Not Enough, 17 Colum. J.L. \& Soc. PrOBS. 45, 56 (1981) ("But though the doctrine is 'thoroughly discredited,' courts continue ritualistically to mouth it." (footnote omitted)). But see United States v. Tonry, 605 F.2d 144, 148 (5th Cir. 1979) (refusing to rely on the act of grace theory of probation); ABA PROBATION STANDARDS, supra note 44, at 385-86 (noting that "probation is a good bit more than the 'matter of grace' or 'leniency' which characterizes the philosophy of the general public and of many judges and legislatures on the subject ${ }^{n}$ ).

${ }^{53}$ See Note, supra note 54, at 191-93 (discussing probation as a contract); see also Greenberg, supra note 57, at 57-60 (same).

${ }^{59}$ See Tonry, 605 F.2d at 148 (refusing to rely on the contract theory of probation); United States v. Consuelo-Gonzalez, 521 F.2d 259, 265 n.15 (9th Cir. 1975) (rejecting the contract theory of probation); People v. Hackler, 16 Cal. Rptr. 2d 681, 683-84 (Ct. App. 1993) (rejecting the contention that the defendant's agreement to the probation condition in the trial court bars his attack on appeal).

${ }^{60}$ See United States v. Mitsubishi Int'l Corp., 677 F.2d 785, 788 (9th Cir. 1982) ("A defendant generally may reject probation and elect to have sentence imposed. For the individual defendant who must accept arguably impermissible conditions of probation or suffer incarceration, this choice is illusory." (citations omitted)); United States v. Pierce, 561 F.2d 735, 739 (9th Cir. 1977) ("As a practical matter, a defendant's consent to a probation condition is likely to be nominal where consent is given only to avoid imprisonment."), cert. denied, 435 U.S. 923 (1978); ConsueloGonzalez, 521 F.2d at 274 (Wright, J., dissenting) ("Consent by the defendant, however, is more likely to be nominal than real. A convicted defendant will often accept almost any alternative to imprisonment ...."). 
In 1984, Congress disavowed these theories of probation when, in the federal Sentencing Reform Act ("SRA"), ${ }^{61}$ it provided that probation constitutes a sentence in itself. ${ }^{62}$ The SRA states that the purposes of sentencing are just punishment, deterrence, incapacitation for public protection, and rehabilitation. ${ }^{63}$ The SRA also includes a widely expanded list of conditions of probation ${ }^{64}$ and clearly indicates that the list is exemplary, not exclusive. ${ }^{65}$

\section{B. Standard of Review: Parameters of Probation Conditions Generally}

The key elements of probation are the conditions it imposes, which allow the courts to simultaneously provide particularized treatment to the offender and protection to the surrounding community. ${ }^{66}$ Under the Federal Probation Act, the SRA, and state authorizing statutes, a sentencing court has broad discretion in determining conditions of probation. ${ }^{67}$ But because probation

${ }^{61} 18$ U.S.C. $\$ \S 3551-3559,3561-3566,3571-3574,3581-3586$ (1988); 28 U.S.C. $\S \S 991-998$ (1988).

${ }^{62}$ See S. REP. No. 225, 98th Cong., 1st Sess. 68 (1984), reprinted in 1984 U.S.C.C.A.N. $3182,3251$.

${ }^{63}$ See 18 U.S.C. § 3553(a)(2); see also Weissman, supra note 51, at 367-68 ("Modern rehabilitative philosophy, or the 'rehabilitative ideal,' is being discarded in favor of determinate sentencing values advocating retribution and equality." (footnote omitted)).

${ }^{64}$ See 18 U.S.C. $\$ 3563(a)$ (listing mandatory conditions of probation, including that the defendant not commit another federal, state, or local crime during the probation term); id. $\$ 3563$ (b) (listing examples of discretionary conditions of probation, including, among others, fines, restitution, community service, and psychiatric counseling).

${ }^{65} \mathrm{See} \S 3563(\mathrm{~b})(21)$ (allowing "other conditions as the court may impose"); see also S. REP. NO. 225, supra note 62 , at 96 ("The list is not exhaustive, and it is not intended at all to limit the court's options-conditions of a nature very similar to, or very different from, those set forth may also be imposed.").

${ }_{66}^{6}$ See Note, supra note 54, at 181 ("The essence of probation is the condition-a judicially imposed restriction upon the convict's actions after release."); see also ABA PROBATION STANDARDS, supra note 44, at 389 (noting that the recommendations on probation conditions are based on the philosophy that "conditions should be individualized for the particular offender"); id. \$3.2(b), at 398 ("Conditions imposed by the court should be designed to assist the probationer in leading a law-abiding life.").

${ }^{67}$ In interpreting the first Federal Probation Act, the U.S. Supreme Court noted that:

To accomplish the purpose of the statute, an exceptional degree of flexibility in administration is essential. It is necessary to individualize each case, to give that careful, humane and comprehensive consideration to the particular situation of each offender which would be possible only in the exercise of a broad discretion. 
is either an alternative to the imposition of a sentence or a sentence itself, conditions of probation must serve the purposes of the criminal law. ${ }^{68}$

The basic test of validity for probation conditions was set forth in Porth v. Templar. ${ }^{69}$ The defendant in Porth was convicted of failure to file tax returns, but the court placed the defendant on probation after suspending imposition of the sentence. As a condition of probation, the defendant was prohibited from speaking, writing, and distributing information questioning the constitutionality of the federal reserve system and the federal income tax laws. ${ }^{70}$ In upholding the probation condition to the extent that it prohibited public speeches designed to incite others to violate the law, ${ }^{71}$ the court held that ${ }^{4}[t]$ he only limitation is that the conditions have a reasonable relationship to the treatment of the accused and the protection of the public." 72

This "reasonable relationship" test ${ }^{73}$ has been further interpret-

Burns v. United States, 287 U.S. 216, 220 (1932); see also ARTHUR W. CAMPBELL, LAW OF SENTENCING § 5.4, at 114 (2d ed. 1991 \& Supp. 1993) ("Perhaps the greatest restriction on permissible probation conditions is limited imagination.").

${ }^{68}$ See United States v. Tonry, 605 F.2d 144, 148 (5th Cir. 1979) ("The judge may, in fact is obliged to, view probation as a substitute for imprisonment and formulate conditions calculated to ensure that the probation furthers the purposes of the criminal law."); see also Arthur, supra note 16, at 37 ("The hallmark of a valid probation condition .... is its ability, by means of coercion, deterrence, or enlightenment, to make future crime less likely. When a condition successfully thwarts future crime, the multiple purposes of rehabilitation, public protection, and facilitation of law enforcement are served.").

${ }^{69} 453$ F.2d 330 (10th Cir. 1971).

${ }^{70}$ See id. at 332 n.1.

${ }^{71}$ Although the court upheld the probation condition to the extent that it prohibited public speeches designed to incite others to violate the law, the court invalidated the condition to the extent it was overbroad. Its overbreadth resulted from the prohibition on the expression of opinions as to the validity of the tax laws. See id. at 334; see also infra notes $149-70$ (discussing the least restrictive alternative standard).

${ }^{72}$ Porth, 453 F.2d at 333.

73 This test has been adopted by many jurisdictions. See, e.g., United States v. Consuelo-Gonzalez, 521 F.2d 259, 264 (9th Cir. 1975) (holding that "the only permissible conditions are those that ... can reasonably be said to contribute significantly both to the rehabilitation of the convicted person and to the protection of the public"); Goldschmitt v. State, 490 So. 2d 123, 125 n.3 (Fla. Dist. Ct. App. 1986) (holding that "the condition should bear some relationship to the nature of the offense of conviction and should have some reasonable rehabilitative basis").

California has adopted a variation on this reasonable relationship test that concludes that a probation condition is invalid if: (1) there is no relationship between the condition and the crime of which the offender was convicted; (2) the condition relates to conduct which is not in itself criminal; and (3) the condition requires or 
ed in Higdon $v$. United States ${ }^{74}$ to require a two-step inquiry. First, a reviewing court must determine that the sentencing court imposed the conditions for permissible purposes. ${ }^{75}$ The Higdon court found that the only permissible purposes of probation are the "appropriateness and attainability for rehabilitation and the need to protect the public." ${ }^{\text {76 }}$ Second, the conditions must be reasonably related to these purposes. ${ }^{77}$

In Higdon, the defendant was convicted of defrauding the government through an elaborate overpayment and kickback scheme. As a condition of probation, the defendant was required to forfeit all assets, including his home, and to work full-time for charity for three years without pay. ${ }^{78}$ The Ninth Circuit reviewed these special conditions of probation after the defendant failed to satisfy the charitable work requirement and the district court revoked probation. The court held that the special conditions were impermissible because "they were not reasonably related to rehabilitation of the offender or protection of the public. ${ }^{\text {79 }}$ The court found that the conditions of probation actually frustrated the rehabilitative purposes of probation, since their "cumulative impact" was so great that they caused Higdon "to falter and to resort to deception." ${ }^{\text {"00 }}$ The court suggested, however, that imposition of one or the other special condition of probation might have been

forbids conduct which is not reasonably related to future criminality. See People v. Lent, 541 P.2d 545, 548 (Cal. 1975); People v. Dominguez, 64 Cal. Rptr. 290, 293 (Ct. App. 1967); see also Thomas E. Bartrum, Note, Birth Control as a Condition of Probation-A New Weapon in the War Against Child Abuse, 80 KY. L.J. 1037, 1040 (1992) (describing the "reasonably related" standard employed by California courts). See generally Greenberg, supra note 57, at 63-77 (further defining reasonable relation tests, as used by different jurisdictions, as facial reasonableness and analytical reasonableness).

${ }^{74} 627$ F.2d 893 (9th Cir. 1980).

${ }^{75}$ See id. at 897.

${ }^{76} \mathrm{Id}$. The Higdon court found that punishment and circumvention of statutory sentencing limits were impermissible purposes of probation. See id. at 898.

77 See id. at 897.

${ }^{78}$ See id. at 896.

${ }^{79} I d$. at 898 . This is the reason that the court explicitly stated for finding the conditions impermissible; however, the court essentially employed a least restrictive alternative analysis in reaching its conclusion. For a discussion of the least restrictive alternative test, see infra notes 149.70 and accompanying text.

${ }^{80}$ Higdon, 627 F.2d at 899-900. When Higdon's probation was revoked, he had served all but eight months of his probation term. See id. at $901 \mathrm{n} .18$. Throughout the probation term, Higdon's circumstances deteriorated greatly. He worked two fulltime jobs to satisfy his probation and support his family; his wife left him; and he developed poor health and a drinking problem. See id. at 896. 
permissible. ${ }^{81}$

Although a sentencing court's discretion is broad, it has been generally agreed that a court's discretion in fixing conditions of probation is further limited by basic standards of criminal law. For instance, a court cannot inflict restrictions as conditions of probation that are improper penal sanctions or that are reserved for application in only a circumscribed class of cases. ${ }^{82}$ Similarly, a court cannot impose restrictions on a probationer as conditions of probation that have been found to be improper conditions of imprisonment or parole. ${ }^{83}$ Finally, a court cannot impose conditions of probation that are "impossible or extremely difficult to satisfy, ${ }^{n 4}$ or those that are too vague as to sufficiently guide the probationer. ${ }^{85}$

\section{Probation Conditions that Infringe CONSTITUTIONAL RIGHTS}

\section{A. Constitutional Rights of Probationers}

The Supreme Court in Griffin v. Wisconsin ${ }^{86}$ recognized that a probationer has a reduced liberty interest. The Court found that probationers have "conditional liberty," depending on special probation restrictions. ${ }^{87}$ Yet probationers retain a higher degree of liberty than their counterparts who are incarcerated. ${ }^{88}$ This

${ }^{81}$ See id. at 899-900. The court suggested that the judge could have imposed a set of conditions "intended to restore Higdon's self-esteem, integrate him into a working environment, and inculcate in him a sense of social responsibility without driving him into penury and deceit." Id. at 900.

${ }^{82}$ See Note, supra note 54 , at $197-98$ (describing this limit on judicial discretion as a unconstitutional limitation).

${ }^{8 s}$ See United States v. Consuelo-Gonzalez, 521 F.2d 259, 264 (9th Cir. 1975) (" [I]t is virtually certain that those restraints that have been held improper when placed on prisoners and parolees will also be unsuitable as probation conditions.").

${ }^{84}$ COHEN \& GOBERT, supra note 29, § 5.08, at 209; see also Sweeney v. United States, $353 \mathrm{~F} .2 \mathrm{~d} \mathrm{10,11}$ (7th Cir. 1965) (finding that a probation condition requiring a chronic alcoholic to refrain from drinking was unreasonable if the probationer could prove that his alcoholism destroyed his ability to abstain).

${ }^{85}$ See People v. McDowell, 130 Cal. Rptr. 839, 843 (Ct. App. 1976) (finding that the wording of the condition as imposed was "not sufficiently precise").

${ }^{86} 483$ U.S. 868 (1987).

${ }^{87} \mathrm{Id}$. at 874 ("To a greater or lesser degree, it is always true of probationers ... that they do not enjoy 'the absolute liberty to which every citizen is entitled, but only ... conditional liberty properly dependent on observance of special [probation] restrictions." (citation omitted)).

${ }^{88}$ As noted by one writer: 
phenomenon has sparked a debate over the extent to which probationers should be accorded constitutional rights. ${ }^{89}$

Many probation conditions implicate constitutional rights in their mission to promote the rehabilitation of the probationer and the protection of the public. Conditions of probation might prohibit the probationer from actively participating in demonstrations that advocate lawlessness, ${ }^{90}$ prohibit the probationer from associating with a certain organization, ${ }^{91}$ or prohibit the probationer convicted of a crime relating to a public or labor union position from becoming involved in political ${ }^{92}$ or union activities. ${ }^{93}$ Similarly, to facilitate law enforcement, a court might impose a condition of probation that requires the probationer to submit to lie detector tests, ${ }^{94}$ psychological counseling, ${ }^{95}$ or disclosure require-

Probationers and parolees walk an interesting line. They dwell among the public with whom they share many of the guarantees of the Bill of Rights, but they remain subject to the strictures of the criminal justice system. Although convicts on probation or parole are not entitled to the same degree of freedom as ordinary citizens, they do retain a broader range of protected liberty interests than persons who are incarcerated.

Arthur, supra note 16, at 60 (footnote omitted).

${ }^{89}$ For a discussion of the various standards currently employed to determine the extent to which probationers should be accorded constitutional rights, see infra notes 117-70 and accompanying text.

${ }^{90}$ See In re Mannino, 92 Cal. Rptr. 880, 886-89 (Ct. App. 1971) (upholding conditions of probation to the extent they prohibited the probationer's active participation in demonstrations), overruled on other grounds, 851 P.2d 802 (Cal. 1993).

${ }^{91}$ See United States v. Schiff, 876 F.2d 272, 276-77 (2d Cir. 1989) (upholding probation condition that prohibited probationer convicted of attempted tax evasion and failure to file a tax return from associating with any group that advocates the violation of tax laws); United States v. Lawson, 670 F.2d 923, 929-30 (10th Cir. 1982) (upholding probation condition that required probationer convicted of failure to file income tax returns and supplying false withholding information to disassociate himself from any organization that had the purpose of defeating the tax laws); United States v. Kohlberg, 472 F.2d 1189, 1190 (9th Cir. 1973) (upholding a condition of probation that prohibited association with any known homosexuals by an offender who was convicted of mailing obscene matter).

${ }_{92}$ See United States v. Tonry, 605 F.2d 144, 150-51 (5th Cir. 1979) (affirming district court's decision that probation condition prohibiting offender of Federal Election Campaign Act from running for political office and from engaging in any political activity that was related to campaigning for political office was valid).

${ }^{93}$ See United States v. Hughes, 964 F.2d 536, 542 (6th Cir. 1992) (upholding condition prohibiting probationer convicted of crimes related to union position from exercising any decision-making authority over union-financed political action committee), cert. denied, 113 S. Ct. 1254 (1993); United States v. Beros, 833 F.2d 455, 467 (3d Cir. 1987) (upholding condition that prohibited probationer convicted of embezzling union funds from holding union position, being employed by any union, representing any union, and receiving any union funds).

9f See People v. Miller, 256 Cal. Rptr. 587, 588-89 (Ct. App. 1989) (upholding 
ments ${ }^{96}$ that might be subject to Fifth Amendment analysis, ${ }^{97}$ or to warrantless searches ${ }^{98}$ that might be subject to Fourth Amendment analysis. ${ }^{99}$

Although the probationer might have conditional liberty interests, these interests are not absolutely limited or reduced. It has been recognized that rehabilitation cannot successfully occur unless there is real change within the offender. ${ }^{100}$ The first step in the rehabilitative process is to develop self-respect and an appreciation for human dignity. Development of these values is a necessary precondition to respecting and abiding by society's values, represented by its laws. ${ }^{101}$ To effectuate these goals, probationers should be guaranteed all fundamental rights except those whose infringement is absolutely necessary to protect the public. ${ }^{102}$

condition that required probationer to submit to polygraph examinations at the direction of his probation officer).

${ }_{95}^{5}$ See United States v. Stine, 675 F.2d 69, 72 (3d Cir. 1982) (affirming the district court's decision that a probation condition requiring psychological counseling was valid).

${ }^{96}$ See United States v. Pierce, 561 F.2d 735, 742 (9th Cir. 1977) (affirming revocation of probation when probationer, convicted of concealing property subject to tax assessment, refused to comply with condition that required financial disclosure), cert. denied, 435 U.S. 923 (1978).

${ }^{97} \mathrm{See}$ U.S. CONST. amend. V (providing in relevant part that no person "shall be compelled in any criminal case to be a witness against himself").

${ }^{93}$ See United States v. Consuelo-Gonzalez, 521 F.2d 259, 263 (9th Cir. 1975) (approving a probation condition that required probationer to submit to a "search of her person or property conducted in a reasonable manner and at a reasonable time by a probation officer").

${ }^{99}$ The Fourth Amendment provides that:

The right of the people to be secure in their persons, houses, papers, and effects, against unreasonable searches and seizures, shall not be violated, and no Warrants shall issue, but upon probable cause, supported by Oath or affirmation, and particularly describing the place to be searched, and the persons or things to be seized.

U.S. CONST. amend. IV.

${ }^{100}$ See, e.g., ROTMAN, supra note 50, at 8 ("Significant change will come only from the individual's own insight, which alone can dissolve the antisocial influences that conditioned his or her mind.").

${ }^{101}$ Rotman notes that rehabilitation "seeks to awaken in [offenders] a deep awareness of their relationship with the rest of society, resulting in a genuine sense of social responsibility." Id. at 77 .

${ }^{102}$ See ABA SENTEncinc STANDARDS, supra note 13 , Std. $18-2.3 \mathrm{cmt}$. , at 97 (explaining that the standards recommend according "the probationer those fundamental rights whose recognition would not clearly impede the objectives of probation"); Melissa Burke, Note, The Constitutionality of the Use of the Norplant Contraceptive Device as a Condition of Probation, 20 HASTINGS CONST. L.Q. 207, 226 (1992) (noting that "many have urged that given the rehabilitative goals of probation, constitutional interests should be protected to the greatest extent possible"). 
"[R]ecognition of the [offender] as a possessor of rights has a secondary rehabilitative effect ... [ [of] increas[ing her] feelings of dignity and self-worth. ${ }^{\text {"103 }}$ There is no better way to ensure that probation meets its goals of rehabilitation and protecting the public than to provide this opportunity for the offender to become a lawabiding member of society. ${ }^{104}$

\section{B. Today's Standard of Review: No Coherent Doctrine}

\section{Probation Conditions that Implicate Fundamental Rights Are Not Summarily Dismissed as Unconstitutional}

It is generally accepted that a condition of probation is not "necessarily invalid simply because it affects a probationer's ability to exercise constitutionally protected rights."105 Indeed, many courts refuse to rely on the Eighth Amendment to limit probation conditions, on the theory that probation does not constitute punishment and that the amendment applies only to punishment. ${ }^{106}$ The other constitutional provisions, however, are not limited to punishment, and while a probationer is generally not accorded the same constitutional protections as nonprobationers, ${ }^{107}$ the Constitution defines the permissible bound-

${ }^{103}$ ROTMAN, supra note 50, at 87 . Rotman also maintains that granting a probationer the legal status as one with rights generates "trust in the legal system, and favors the possibility of self-command and responsible action within society." Id. at 77.

104 See David Dressler, Practice and Theory of Probation and Parole 124 (1959) ("But the most effective community protection is that which results from change within the offender, so that he no longer wants to aggress against society.").

${ }^{105}$ United States v. Tonry, 605 F.2d 144, 150 (5th Cir. 1979).

${ }^{106}$ See, e.g., Springer v. United States, 148 F.2d 411, 415 (9th Cir. 1945) ( $[$ [C]onditions of probation are not punitive in character and the question of whether or not the terms are cruel and unusual and thus violative of the Constitution of the United States does not arise for the reason that the Constitution applies only to punishment."); Burke, supra note 102, at 240 (noting that because it is not offered as a form of punishment, a "court may well view a probation condition that is part of a rehabilitative plan as immune to an Eighth Amendment challenge"). But see Hink, supra note 35 , at 489 ("If the court admits that probation is intended to substitute a milder form of retribution for the original punishment, how can it follow that probation must not meet at least the same degree of constitutional limitation against cruel and unusual terms?"); Jon A. Brilliant, Note, The Modern Day Scarlet Letter: A Critical Analysis of Modern Probation Conditions, 1989 DUKE L.J. 1357, 1377, 1381-84 (advocating that because many probation conditions indeed constitute punishment, courts should subject them to Eighth Amendment scrutiny).

${ }^{107}$ See Porth v. Templar, 453 F.2d 330, 334 (10th Cir. 1971) ("This is not to say that one on probation has the rights of citizens who are not on probation."). 
aries of probation conditions.

Courts generally subject probation conditions that restrict constitutional rights to "special scrutiny. ${ }^{\text {"108 }}$ Thus, when constitutional liberties are implicated, the condition of probation is subject to a second level of scrutiny ${ }^{109}$ beyond the basic "reasonable relationship" test outlined in Porth. In United States v. ConsueloGonzalez, ${ }^{110}$ the Ninth Circuit set forth the test to determine whether a condition of probation impermissibly infringes a constitutional right. ${ }^{111}$ The probationer in Consuelo-Gonzalez, convicted of heroin smuggling, was required as a condition of probation to submit to warrantless searches by any law enforcement agent. The court held that the appropriate inquiry is not whether the rights restricted by the condition would be accorded preference under the traditional constitutional analysis, but whether the restrictions are primarily designed to meet the goals of probation. ${ }^{112}$ The court then examined the following three factors: the purposes of probation, the extent to which the full constitutional guarantees available to nonprobationers should be accorded probationers, and the legitimate needs of law enforcement. ${ }^{113}$

Employing this test, the Ninth Circuit found that the condition of probation was improper. ${ }^{114}$ In determining the scope of constitutional protection available to the probationer, the court found that the probation condition was overbroad because it

${ }^{108}$ See United States v. Consuelo-Gonzalez, 521 F.2d 259, 265 (9th Cir. 1975) ("Conditions that unquestionably restrict otherwise inviolable constitutional rights may properly be subject to special scrutiny to determine whether the limitation does in fact serve the dual objectives of rehabilitation and public safety."); see also United States v. Hughes, 964 F.2d 536, 542 (6th Cir. 1992) ("A district court may include conditions that restrict fundamental rights, such as freedom of speech and freedom of association, although in such cases we must review the restrictions with particular care."), cert. denied, 113 S. Ct. 1254 (1993).

${ }^{109}$ Indeed, this more demanding level of scrutiny determines the validity of the probation condition. See Bartrum, supra note 73, at 1044 (abandoning the specific "reasonable relationship" test adopted by each jurisdiction because the "validity of a condition of probation truly hinges on the additional level of scrutiny imposed").

${ }^{110} 521$ F.2d 259 (9th Cir. 1975).

${ }^{111}$ Jurisdictions differ in their exact approach and semantics regarding this additional level of scrutiny imposed. See Arthur, supra note 16, at 67 ("In the absence of a unifying directive from the country's highest court, jurisdictions will probably continue to apply a divergent array of methods to test the constitutionality of probation conditions that impinge fundamental rights."). This Comment focuses on the Consuelo-Gonzalez test as representative of the factors courts consider.

${ }^{112}$ See 521 F.2d at 265 n.14.

${ }^{113}$ See id. at 262.

${ }^{114}$ See id. at 263. 
permitted searches that "could not [have] possibly serve[d] the ends of probation." 115 The court thus suppressed evidence obtained pursuant to a search authorized by the improper condition. ${ }^{116}$

\section{The Extent to Which Probationers Should Be Accorded Constitutional Rights}

The crux of the standard of review as defined by the ConsueloGonzalez court is the second prong, which requires determining the extent to which the probationer should be accorded constitutional rights. In the absence of any unifying directive from the Supreme Court, jurisdictions have developed different approaches to this key element. Generally there are three such approaches: the reasonableness standard, the balancing standard, and the least restrictive alternative standard. ${ }^{17}$

\section{a. The Reasonableness Standard}

The reasonableness standard requires that the probation condition be not merely reasonably related to the purposes of probation, but that the condition be reasonable. While the baseline "reasonably related" test focuses on the directness of the relationship between the probation condition and the purposes of probation, the reasonableness test scrutinizes the severity of the condition in light of the crime for which the offender was convicted. In United States $v$. Beros, ${ }^{118}$ for example, the Third Circuit upheld a condition of probation that prohibited the offender from holding an elected position within the union or from otherwise obtaining authority to receive or control union funds. ${ }^{119}$ After the court engaged in the first-level reasonably related test, ${ }^{120}$ it considered the condition against a First Amendment constitutional challenge.

${ }^{115} I d$, at 265 . The court came to this conclusion because by authorizing warrantless searches conducted by any law enforcement agent, the condition permitted "an intimidating and harassing search to serve law enforcement ends totally unrelated to either [the probationer's] prior conviction or her rehabilitation." Id. The court suggested that a probation condition authorizing warrantless searches to be conducted only by probation officers, however, would be permissible. See id. at 266.

${ }^{116}$ See id.

117 See Bartrum, supra note 73, at 1041-45.

118833 F.2d 455 (3d Cir. 1987).

119 See id. at 467.

${ }^{120}$ See id. (finding that " $[\mathrm{i}] \mathrm{n}$ this case, the condition of probation imposed was well suited to effect the legitimate governmental purposes"). 
The court held that "significant impositions upon an individual's first amendment rights may well be reasonable in light of the offense for which that individual was convicted." 121 The court concluded that because the offender was validly convicted of several counts of embezzlement and misuse of union funds, the prohibitions on holding elective office and obtaining authority to receive union funds were reasonable. ${ }^{122}$

Similarly, in United States $v$. Schiff, ${ }^{123}$ the Second Circuit employed a reasonableness test in considering whether a condition of probation passed constitutional muster. The probationer in Schiff was convicted of attempted tax evasion and willful failure to file a corporate tax return. ${ }^{124}$ Indeed, the court found that the probationer was a "professional tax resister." 125 As a special condition of probation, the district court prohibited the probationer from associating with any group that advocated noncompliance with or violation of the tax laws. ${ }^{126}$ In upholding the condition against the probationer's First Amendment challenge, the court noted that it had "upheld probation conditions that restrict a person's liberty before, when, as here, those conditions bear a reasonable relation to the crime of which the defendant stands convicted. ${ }^{127}$ The court then found that the probation condition was reasonable in light of the underlying conviction. ${ }^{128}$

While many courts employ this test of reasonableness, ${ }^{129}$ such a test provides insufficient protection to a probationer's constitutional rights. First, the test purports to submit probation conditions that restrict a probationer's liberty interests to a level of analysis beyond the baseline reasonably related standard; in reality, however, it affects little more than a further inquiry into the same question.

${ }^{121} \mathrm{Id}$.

${ }^{122}$ See id. The court failed to articulate specifically how it determined that the condition was reasonable.

${ }^{123} 876$ F.2d 272 (2d Cir. 1989).

124 See $i d$. at 273.

${ }^{125}$ Id. (citation omitted).

${ }^{126}$ See id. at 274 .

${ }^{127} \mathrm{Id}$. at 276.

${ }^{128}$ The court agreed with the district court that "it is entirely reasonable to prohibit a person convicted of attempted tax evasion from participating in meetings designed to advocate just such unlawful activity." Id. at 277.

${ }^{129}$ The Ninth Circuit has also employed a variation of this reasonableness test. See United States v. Lowe, 654 F.2d 562, 567-68 (9th Cir. 1981) ("The probation condition reasonably meets the goal of keeping the peace and deterring further criminal activity. . . . Keeping the defendants away from the fence was a logical means of prevention." (emphasis added)). 
Although the reasonableness standard explicitly considers the crime of which the probationer was convicted, the crime is already considered in the reasonably related test's inquiry into whether the probation condition will serve to rehabilitate the offender. Rehabilitation potential cannot be determined without an examination of the crime itself. Thus, the reasonably related test already serves the function of the supposedly second-level reasonableness analysis. Indeed, the reasonableness test may result in a purely semantic inquiry, since a court can meet the standard without having to evaluate any additional information. ${ }^{130}$

Second, the reasonableness standard fails to consider the nature of the constitutional interest that the probation condition restricts. It is generally agreed that some constitutional rights are valued more highly than others. ${ }^{131}$ The reasonableness standard neglects to account for the kind of constitutional interest infringed on by the probation condition and therefore inadequately protects those interests that are more fundamental than others.

\section{b. The Balancing Standard}

The balancing test requires a court to balance the government's interest in conditioning probation against the probationer's liberty interest. In United States $v$. Pierce, ${ }^{132}$ the Ninth Circuit engaged in this type of analysis in determining whether a probation condition

${ }^{130}$ See Hink, supra note 35 , at 488 . Hinks suggests that "on the whole it appears that the cases interpreting 'reasonable' have not added much content to probation standards." Id. (citing People v. Blankenship, 61 P.2d 352 (Cal. 1936) (finding it a reasonable condition of probation that the syphilitic defendant, convicted of statutory rape, submit to a vasectomy)). Hink criticizes the reasonableness standard because it fails to prevent future criminal behavior by the probationer. See id. In Blankenship, for example, the probation condition merely prevented the defendant from fathering a child; it did not, however, prevent the defendant from committing another rape. See id.

${ }^{131}$ Some constitutional rights are deemed fundamental, some preferred, and some lesser. For instance, if an interest is fundamental, the court will subject any infringement of that interest to the most stringent test, which requires that the infringement be necessary to serve a compelling state interest. See Harper v. Virginia Bd. of Elections, 383 U.S 663, 670 (1966) (characterizing the right to vote as fundamental and therefore subjecting state poll tax to strict scrutiny). For a lesser constitutional interest, for example, an economic interest, any infringement must meet only the less stringent test of being rationally related to a legitimate state interest. See Williamson v. Lee Optical, 348 U.S. 483, 488 (1955) (upholding a restriction on fitting and duplicating eyeglass lenses by opticians because " $[\mathrm{i}] \mathrm{t}$ is enough ... that it might be thought that the particular legislative measure was a rational way to correct it"). See generally TRIBE, supra note 31, $\$$ 11-1, 16-6, 16-7.

132561 F.2d 735 (9th Cir. 1977), cert. denied, 435 U.S. 923 (1978). 
was unconstitutional. The condition at issue required the probationer, who pleaded guilty to concealing property subject to a tax assessment, to testify under oath to the U.S. Attorney's Office on "all questions as to his financial condition relating to amounts and locations of all assets. ${ }^{n 33}$ After determining that the condition was reasonably related to the purposes of probation, ${ }^{134}$ the court inquired whether the condition "involve[d] a proper accommodation between the need for information and those Fifth Amendment rights which [the probationer] retains. ${ }^{n 135}$ The court proposed a balancing approach to "facilitate [such] an accommodation between the practical needs of the probation system and the constitutional guarantees of the Bill of Rights. ${ }^{\text {136 }}$

The Pierce court ultimately upheld revocation of probation on the ground that the probationer failed to show that the probation condition was unconstitutional. The court found that the probationer waived any Fifth Amendment right he might have had when he failed to produce information within the scope of the condition and did not provide a justification for failing to do so. ${ }^{137}$ Therefore, the court did not complete its stated task of balancing the probationer's liberty interests against the state's interests in law enforcement. ${ }^{138}$

The district court in United States $v$. Stine, ${ }^{139}$ however, employed a balancing test in upholding a condition of probation against a First Amendment challenge. Stine was convicted of illegally receiving a firearm and, as a condition of probation, was required to satisfactorily complete a program of psychological counseling. ${ }^{140}$ In response to Stine's motion to correct an illegal sentence, the district court held that it must undertake a "balancing

13s Id. at 738.

${ }^{134}$ See id. at $739-40$.

${ }^{135}$ Id. at 740.

${ }^{136} I d$. at 739 .

${ }^{137}$ See id. at $741-42$.

${ }^{138}$ See id. at 742. Although the Pierce court stated that it would use the balancing test, the Ninth Circuit has been ambivalent about fully employing this test. See, e.g., United States v. Lowe, 654 F.2d 562, 569 (9th Cir. 1981) (Boochever, J., dissenting) (advocating that the court should "balance the probational benefits against the restriction on the exercise of first amendment rights" and therefore conclude that "under the circumstances of this case the restriction is unwarranted"). The Lowe majority employed the lesser "reasonableness" test, however, and thus upheld the probation condition. See id. at 567-68.

${ }^{139} 521$ F. Supp. 808 (E.D. Pa. 1981), affd, 675 F.2d 69 (3d Cir.), cert. denied, 458 U.S. 1110 (1982).

${ }^{140}$ See id. at 809. 
of defendant's constitutional rights with society's right to be protected from further criminal acts by a convicted felon who remains free."141 The court, however, did not expressly weigh the probationer's privacy rights against society's rights. Instead, the court concluded that society required protection from the probationer; the court never questioned that the probationer's privacy rights would be compromised. The court's function was reduced to determining the extent to which those privacy rights would be restricted. ${ }^{142}$ The court therefore upheld the condition that required psychological counseling without explicitly considering the weight of the probationer's First Amendment rights. ${ }^{143}$

Although the balancing standard has been used by several courts, this standard insufficiently protects fundamental rights of probationers. As employed by courts, the balancing standard is very fact-specific; each subsequent court is, in practice, left without guidance to initially weigh the interests at issue. ${ }^{144}$ As a result, "the test allow[s] a court to reach either conclusion in almost every case. ${ }^{n 145}$ Furthermore, this standard does not explicitly require consideration of less restrictive alternatives. ${ }^{146}$ Under this standard, a court can still impose conditions of probation that unnecessarily restrict constitutional rights that are essential to both our underlying theories of democracy ${ }^{147}$ and probation's rehabilitative potential. ${ }^{148}$

${ }^{141} \mathrm{Id}$. at 811 .

142 “[Society's protection] could be accomplished by either incarcerating defendant or rehabilitating him. ... [P]sychological counseling could achieve rehabilitation, by far the less restrictive alternative." Id.

${ }^{143}$ See id. at 812 . On appeal, the Third Circuit upheld the probation condition. See Stine, 675 F.2d at 72.

144 This criticism has been summarized as follows:

The principal difficulty with the ad hoc balancing test is that it frames the issues in such a broad and undefined way, is in effect so unstructured, that it can hardly be described as a rule of law at all. As a legal doctrine for affording judicial protection to a system of free expression, it is not tenable.

Thomas I. Emerson, Toward a General Theory of the First Amendment, 72 YALE L.J. 877, 912 (1963).

${ }^{145}$ Id. at 913.

${ }^{146}$ While the Stine court concluded that psychological counseling was the "less restrictive alternative," $521 \mathrm{~F}$. Supp. at 811 , it considered the probation condition against the alternative of incarceration. Faithful application of the least restrictive alternative standard, however, requires consideration of alternative probation conditions other than the one proffered. See infra notes 149-61 and accompanying text.

${ }^{147}$ See supra notes 29-32 and accompanying text (discussing the First Amendment as a fundamental right).

${ }^{148}$ See infra notes 265-71 and accompanying text (discussing the importance of 


\section{c. The Least Restrictive Alternative Standard}

The least restrictive alternative, or "necessary," standard upholds a condition of probation that infringes a constitutional right only if that condition is the least restrictive alternative in meeting permissible purposes of probation. For example, the Ninth Circuit in United States $v$. Terrigno ${ }^{149}$ applied such an analysis in determining whether a condition of probation was unconstitutional. The Terrigno defendant was convicted of embezzlement and conversion of public funds and, as a condition of probation, she was prohibited from receiving any financial remuneration or any other thing of value for speaking engagements, written publications, movies, or any other media coverage dealing with her offense. ${ }^{150}$ Terrigno objected to the probation condition on the ground that it restricted her First Amendment right to speech. The court, however, disagreed and upheld the condition on the ground that it "only forbids Terrigno's making a profit, it does not restrict expression at all, and the restriction obtains only during her probation term." ${ }^{n 151}$ The court thus applied the principle that "if conditions are drawn so broadly that they unnecessarily restrict otherwise lawful activities they are impermissible." 152 Additionally, the court found the condition to be a particularly effective way to remind Terrigno, in a very practical sense, that "crime does not pay." ${ }^{153}$

First Amendment rights in maximizing the potential of probation to serve its primary goal of rehabilitation).

14938 F.2d 371 (9th Cir. 1988).

${ }^{150}$ See id. at 373; see also United States v. Waxman, 638 F. Supp. 1245, 1247 (E.D. Pa. 1986) (similarly imposing a prohibition on remuneration as a probation condition). The Waxman court upheld the following inclusive condition of probation against a First Amendment challenge:

He shall not profit financially or through the receipt of any property from the sale of any TV or radio scenario, nor shall he cooperate with any writer or author in the preparation of any such work if any member of his family or any friend might profit thereby. He is not to profit from the sale of any book or magazine article prepared about his life or experiences, nor shall he cooperate with any author if any member of his family, or any friend might profit thereby.

Id. at 1246. The Waxman court intended the condition to preclude the defendant "from obtaining any profit or financial benefit or in any way capitalizing upon his art theft or subsequent treatment and this provision shall be construed broadly." Id.

${ }^{151}$ Terrigno, $838 \mathrm{~F} .2 \mathrm{~d}$ at 374-75. The Waxman court similarly found that the defendant "may speak to whom he wishes or write what he wants. The only restriction is that he not be paid for doing so." Waxman, 638 F. Supp. at 1246.

152 Terrigno, 838 F.2d at 374.

${ }^{15 s}$ See id. The Waxman court expressed a similar sentiment: 
State courts have also adopted the least restrictive alternative test. For example, in People v. Pointer ${ }^{154}$ a California Court of Appeal ruled impermissible a condition forbidding the probationer from conceiving a child during the probationary term. Pointer was convicted of child endangerment as a result of imposing a strict macrobiotic diet on her two young children, after repeated advice from her doctors that such a diet was hazardous to children. The court's first level of analysis found the condition of probation to be reasonably related to both the crime for which Pointer was convicted and possible future criminality, since Pointer's conduct before giving birth might endanger the child. ${ }^{155}$ The court, however, struck the condition as invalid because "less restrictive alternatives [were] available. ${ }^{156}$ For instance, the court suggested that pregnancy testing, followed by a strict prenatal and neonatal health program and removal of the child into foster care if necessary, would serve the goals of probation while infringing less on Pointer's constitutional rights. ${ }^{157}$

Courts have also implicitly relied on the least restrictive alternative test while promoting, by semantics, one of the other tests. In United States $v$. Lawson ${ }^{158}$ the Tenth Circuit upheld a condition of probation requiring the probationer to "disassociate himself with any organization that has as its purpose defeating the Internal Revenue Service laws." ${ }^{\text {159 }}$ The court contrasted the condition of probation at issue from others that prohibited association with groups that express opinions as to the invalidity or unconstitutionality of the tax laws. ${ }^{160}$ The court recognized that the latter conditions were unnecessarily restrictive, and therefore construed the condition at issue to involve "only organizations advocating disobedience" of the tax laws. ${ }^{161}$

[I]t is in his own interest for [the defendant] to learn that society will neither tolerate criminal behavior nor permit the criminal to profit from it when he can be prevented from doing so. . . . [I]t is also in the interest of other members of society to learn by example that not only may they have to pay the piper but that they cannot expect the piper to pay them for their memoirs.

Waxman, 638 F. Supp. at 1246.

154199 Cal. Rptr. 357 (Ct. App. 1984).

155 See id. at 364 .

${ }^{156} \mathrm{Id}$. at 366.

${ }^{157}$ See id. at 365.

${ }^{158} 670$ F.2d 923 (10th Cir. 1982).

159 Id. at 929.

${ }^{160} \mathrm{See}$ id.

${ }^{161} \mathrm{Id}$. at 930 . In its analysis, the court explicitly relied on the reasonably related 
The least restrictive alternative standard most effectively meets the purposes of probation by determining the conditions of probation that provide meaningful opportunity for rehabilitation in conjunction with sufficient public protection. Meaningful opportunity for rehabilitation implies the chance to learn to live within the community. ${ }^{162}$ The likelihood that a probationer will learn to do so successfully is increased by the imposition of probation conditions that interfere in the least drastic way with normal community living. Indeed, commentators who suggest that rehabilitation is a right advocate the least restrictive setting to achieve such rehabilitation. ${ }^{163}$

As noted earlier, recognition of the offender as a person with legal rights is the first step toward the offender's development of a sense of self-respect and an appreciation for human dignity. ${ }^{164}$ Only when the probationer develops these values will she be able to transform them into respect for society as a whole. Because the least restrictive alternative standard guarantees to an offender all fundamental rights except those whose infringement is absolutely necessary to protect the public, application of this standard provides the probationer the most meaningful opportunity to develop the self-respect and appreciation for human dignity that are necessary to respect society and its laws without compromising protection of the public. ${ }^{165}$

Furthermore, the least restrictive alternative analysis identifies

test. See id. at 929.

${ }^{162}$ See ABA PROBATION STANDARdS, supra note 44, at 385 ("Other things being equal, the odds are that a given defendant will learn how to live successfully in the general community if he is dealt with in that community rather than shipped off to the artificial and atypical environment of an institution of confinement."); supra notes 49-50 and accompanying text (discussing probation as a means of reintegrating the offender into society).

${ }^{163}$ See ROTMAN, supra note 50, at 155. Rotman proposes the following:

If rehabilitation is seen as a right, it cannot be used as a pretext to impose restrictions greater than are essential to further legitimate governmental interests. Rather, the recognition of a right to rehabilitation implies the use of the least restrictive setting, minimal intrusion, and the least drastic methods by which legislative aims can be achieved. Id.

16t See supra notes 100-04 and accompanying text.

165 Indeed, application of the least restrictive alternative standard illuminates the notion that rehabilitation and public safety are not mutually exclusive goals. See DRESSLER, supra note 104, at 84 ("But fundamentally, the best community protection lies in so helping those who have offended that they no longer want to offend and no longer do violate the law."). 
the part, if any, of the probation condition that is valid. By using this standard, a court can invalidate the portion of the probation condition that is invalid and at the same time retain the permissible portions. ${ }^{166}$ This method promotes judicial economy by avoiding reliance by a reviewing court on remands that allow the lower court to impose additional and permissible conditions of probation.

The least restrictive alternative test has been criticized for being too lenient on the probationer. It has been contended that the test fails to recognize that probationers have reduced liberty interests since the test provides probationers the same level of protection as that afforded nonprobationers. ${ }^{167}$ While the basic analysis of this criticism is correct, this contention fails to acknowledge that the substantive prohibitions and requirements embodied in probation conditions can never be applied to nonprobationers. The imposition of the prohibition or requirement stems solely from the probationer's status as a person convicted of a crime. For example, prohibiting a nonprobationer from receiving money for speaking engagements would not even satisfy the compelling state interest analysis, while the same prohibition imposed as a condition of probation has been upheld. ${ }^{168}$ Therefore, the least restrictive alternative test adequately provides a distinction between probationers and nonprobationers while at the same time affording fundamental constitutional interests the protection necessary to comport with our basic values of democracy ${ }^{169}$ and probation's rehabilitative potential. ${ }^{170}$ Furthermore, constitutional "standards" them-

${ }^{166}$ See Greenberg, supra note 57, at 79 ("Overbreadth analysis complements reasonableness by screening out those portions of an otherwise valid condition which bear no relation to probation's purposes, while reasonableness invalidates only totally unrelated terms.").

${ }^{167}$ The traditional constitutional analysis applied to a state action that infringes a fundamental right requires that the infringement be necessary to meet a compelling state interest. See, e.g., Kramer v. Union Free Sch. Dist., 395 U.S. 621, 630 (1969) (holding that restrictions limiting the fundamental right to vote must be "necessary to promote a compelling state interest"). Therefore, an overbroad infringement of a fundamental interest is unconstitutional. For a discussion of this criticism of the least restrictive alternative test, see Bartrum, supra note 73, at 1045.

${ }_{168}$ See United States v. Terrigno, 838 F.2d 371, 373 (9th Cir. 1987); United States v. Waxman, 638 F. Supp. 1245, 1247 (E.D. Pa. 1986); supra notes 149-53 and accompanying text.

${ }^{169}$ See supra notes 29-32 and accompanying text (discussing the First Amendment as a fundamental right).

${ }^{170}$ See infra notes 265-71 and accompanying text (discussing the importance of First Amendment rights in maximizing the potential of probation to serve its primary goal of rehabilitation). 
selves should not vary because of the types of persons involved, even though constitutional "rights" might.

Confusion in the courts in articulating a clear standard by which to judge probation conditions that implicate constitutional rights results in inadequate protection of fundamental rights. ${ }^{171}$ While most probation conditions are prohibitive in nature, recent conditions of probation place an affirmative obligation on the probationer that implicates fundamental rights. Because of their unique character, these affirmative probation conditions must be analyzed separately.

\section{Affirmative Probation Conditions that INFRINGE FIRST AMENDMENT RIGHTS}

\section{A. Examples}

Most of the probation conditions that infringe First Amendment rights are prohibitive in nature. The probationer is forbidden from expressing opinions in certain ways, ${ }^{172}$ from associating with certain people or groups, ${ }^{173}$ or from holding office or employment in a specific type of organization. ${ }^{174}$ In some instances, however, conditions of probation place an affirmative obligation on the probationer that implicates First Amendment rights. Such conditions can generally be divided into two categories: those that serve to notify the public of the offense and those that serve to associate the probationer with a certain ideology.

\section{Probation Conditions that Serve Public Notice}

Several courts have imposed conditions of probation that affirmatively require the probationer to advertise her wrongdoing to the public. In United States $v$. Clark, ${ }^{175}$ the Ninth Circuit reviewed the constitutionality of such a condition. The Clark probationers were police officers for the Oakland Police Department who instituted a civil rights lawsuit against the City of Oakland for discriminating against them and for committing retaliatory acts

${ }^{171}$ See supra notes $118-48$ and accompanying text (discussing the reasonableness test and the balancing test).

172 Through advocating incitement or active participation in political demonstrations, for example. See supra notes $69-71,90$ and accompanying text.

${ }^{173}$ See supra notes $47,91,123-28$ and accompanying text.

${ }^{174}$ See supra notes $92-93,118-22$ and accompanying text.

175918 F.2d 843 (9th Cir. 1990). 
against them after they had filed an earlier complaint with the Equal Employment Opportunity Commission. ${ }^{176}$ Discovery efforts in connection with the civil rights lawsuit revealed that the officers had misrepresented material facts of the underlying claim; they were charged with and ultimately convicted of perjury. ${ }^{177}$ The officers were granted probation on the condition that they publish an apology in both the local newspaper and the police department's newsletter. ${ }^{178}$

The Ninth Circuit upheld the probation condition against a First Amendment challenge as within the sentencing court's discretion. ${ }^{179}$ The court found the record to support a conclusion that the sentencing judge imposed the condition for purposes of rehabilitation. Further, the court held that because neither officer had admitted guilt or taken responsibility for her actions, "a public apology may serve a rehabilitative purpose."180 The court noted that the first step toward rehabilitation is the offender's recognition of fault. ${ }^{181}$

Another example of an affirmative probation condition that serves as public notice of an offense is the requirement that offenders convicted of driving under the influence ("DUI") affix to their cars a bumper sticker to that effect. Although commentators have referred to such a probation condition as a "scarlet letter, ${ }^{n 182}$

${ }^{176}$ See id. at 844.

${ }^{177}$ See id. at 844-45.

${ }^{178} \mathrm{See} i d$. at 845 . The required apology stated:

My name is [Johnnie Clark/Theresa Jeffery]. I am a former Oakland Police Officer. On March 7, 1989, I was convicted by a jury verdict of perjury.... . I acknowledge that I have betrayed the trust and confidence placed in me as a police officer by lying, and I recognize that I have undermined reasonable efforts to achieve a racially unbiased workplace... . I regret my wrongdoing and apologize for my misdeeds.

Id.

${ }^{379}$ See id. at 848 (holding that "[b]ecause the probation condition was reasonably related to the permissible end of rehabilitation, requiring it was not an abuse of discretion").

${ }^{180}$ Id.; see also Brilliant, supra note 106 , at 1363 (noting that one judge who imposes public apology probation conditions believes that "'an open and public admission ... make[s] it more likely that the defendant will not commit further crimes'" (citation omitted)).

${ }^{181}$ See Clark, 918 F.2d at 848 ("It is almost axiomatic that the first step toward rehabilitation of an offender is the offender's recognition that he was at fault." (quoting Gollaher v. United States, 419 F.2d 520, 530 (9th Cir.), cert. denied, 396 U.S. 960 (1969))).

${ }^{182}$ Brilliant, supra note 106 , at $1362-64$ (referring to a probation condition requiring a drunk driver to put a bumper sticker on his car as a modern day "scarlet 
a Florida court upheld the condition in Goldschmitt $v$. State. ${ }^{183}$ Goldschmitt objected to the probation condition on the ground that when the state compelled him to affix the bumper sticker to his car, ${ }^{184}$ it violated the First Amendment. The court rejected this argument, however, because it found that the required bumper sticker did not contain an ideological message. ${ }^{185}$

State $v$. Bateman ${ }^{186}$ serves as a final example of a probation condition that notifies the public of the offense. The offender in Bateman was convicted of sexual abuse and subsequently placed on probation, on the condition that he post signs on his residence and on his car reading "Dangerous Sex Offender." ${ }^{187}$ The court affirmed the sentencing court on the procedural ground that neither the scope of review nor the applicable statute allowed the court to determine the validity of the condition. ${ }^{188}$

The Bateman condition of probation is similar to that in Goldschmitt, in that it serves as a public warning. A concurring opinion in Bateman noted that the trial judge intended that the required signs warn the public of the danger posed by the probationer. ${ }^{189}$ In this way, the trial court created the condition of probation to meet probation's goal of public safety. ${ }^{190}$ Similarly, although the above examples demonstrate that an affirmative obligation imposed as a condition of probation implicates First

letter ${ }^{n}$ ). See generally Dan Connally, Note, When Hester Prynne Drives Drunk: An Examination of the Constitutional Challenges to the Requirement of a "Scarlet Bumper Sticker" as a Condition of Probation on DUI Offenses, 41 OKLA. L. REV. 529 (1988). For the related issue of the propriety of publicity as a probation condition for corporations, see generally Andrew Cowan, Note, Scarlet Letters for Corporations? Punishment by Publicity Under the New Sentencing Guidelines, 65 S. CAL. L. REv. 2387 (1992).

${ }^{183} 490$ So. 2d 123 (Fla. Dist. Ct. App. 1986).

${ }^{184}$ The bumper sticker read "CONVICTED D.U.I.-RESTRICTED LICENSE." Id. at 124.

185 "Suffice it to say ... that the message involved in the present case is "no more ideological than a permit to park in a handicapped parking space' ... . Id. at 125 (citation omitted). For examples of conditions that implicate First Amendment rights by imposing ideological messages, see infra notes 191-213 and accompanying text.

185771 P.2d 314 (Or. Ct. App. 1989).

${ }^{187} I d$. at 316.

${ }^{183}$ See id. at 319.

${ }^{189}$ See id. (Riggs, J., concurring) ("The community has a right to know that $\mathrm{Mr}$. Bateman is a dangerous sex offender." (quoting the trial judge)); see also Brilliant, supra note 106, at 1366 (quoting the trial judge as responding to the "lack of community recognition of dangerous people'").

${ }^{190}$ See Bateman, 771 P.2d at 320 (Riggs, J., concurring) (noting that the "condition of probation imposed in this case was only one of several conditions of probation and was primarily designed to provide protection to the public in the light of the fact that defendant's previous jail sentence for a similar offense has failed"). 
Amendment interests, the condition directly serves to notify and thereby protect the public.

\section{Probation Conditions that Impose an Ideology}

Some sentencing courts have gone so far as to require that the probationer, as a condition of probation, associate or become associated with a particular ideology. These efforts have generally been the result of an attempt to educate or to reform the probationer. For example, a type of probation condition imposed on offenders requires the offender to either become a member of or contribute money to a political advocacy organization. In a recent case, ${ }^{191}$ the offender pleaded guilty to violating several environmental statutes. As a condition of his probation, the offender was required for the duration of his five-year probationary term to become a member in good standing of the Sierra Club, a political advocacy organization that lobbies and litigates on behalf of environmental causes. ${ }^{192}$ Similarly, a commercial hunting guide and his brother who pleaded guilty to federal hunting charges were required to contribute fifty dollars each to the National Wildlife Federation as a condition of their probation. ${ }^{193}$ The National Wildlife Federation is also a political advocacy organization that lobbies on behalf of environmental and conservation issues. This type of probation condition has not been limited to the context of environmental crimes: a New York court required a probationer convicted of attempted criminal possession of a weapon to contribute $\$ 2500$ to an organization politically advocating gun control. ${ }^{194}$

Another type of probation condition requires the offender to associate with an organization or a program that promotes religion. ${ }^{195}$ The trial court in Owens $v$. Kelley ${ }^{196}$ imposed on the

${ }^{191}$ See Ohio v. Bohnert, No. B91-2520 (C.P. Hamilton County, Ohio Nov. 6, 1991).

192 The Sierra Club is not characterized as a charitable organization under Internal Revenue Service rules because of its advocacy and lobbying activities. See SIERRA Club, ANNUAL REPORT 1990-1991, at 11 (1992); see also Cruel and Unusual Punishment, supra note 7, at 9 (describing another Ohio case in which the owner of an electroplating company pleaded guilty to violations of the state's hazardous waste laws and was placed on probation on the condition that he become a member in good standing of the Sierra Club).

${ }^{193}$ See Hunting Guide Sentenced, supra note 7, at 5A.

194 See People v. Warren, 452 N.Y.S.2d 50 (App. Div. 1982) (describing the holding of the trial court). The appeals court reviewing this condition of probation held it invalid. See id. at 51 ("We find invalid the imposition of a contribution that would advance one side of this controversy.").

${ }^{195}$ For a recent example of a probation condition that explicitly required the 
probationer, who was convicted of violating the state's controlled substances act, a requirement that he participate in a criminal rehabilitation program entitled Emotional Maturity Instruction ("EMI"). ${ }^{197}$ The probationer objected on the grounds that the EMI program was religiously oriented, but the district court granted summary judgment in favor of the state, finding no genuine issues of material fact based on written materials that described the EMI program. ${ }^{198}$

The Eleventh Circuit reversed, however, because it found that there was a clear factual dispute as to the content and nature of the oral instruction of the EMI program. ${ }^{199}$ In remanding consideration of the nature of the EMI program's oral instruction, the court noted that

a condition of probation which requires the probationer to adopt religion or to adopt any particular religion would be unconstitutional. It follows that a condition of probation which requires the probationer to submit himself to a course advocating the adoption of religion or a particular religion also transgresses the First Amendment. ${ }^{200}$

The court therefore recognized an additional boundary beyond which a probation condition could not stand.

Similarly, the trial court in Wamer v. Orange County Department of Probation $^{201}$ required that the probationer become associated with a particular religious ideology. Warner was convicted of. driving while ability-impaired, his third such offense within approximately a year. ${ }^{202}$ The trial court imposed a seemingly innocuous, and very common, condition of probation: that the probationer attend Alcoholics Anonymous ("AA"). ${ }^{203}$ Warner, however, objected to the condition on the ground that mandatory

defendant and her four children to attend weekly church services for one year, see U.S. Judge Orders Woman to Go to Church for a Year, N.Y. TIMES, Feb. 11, 1994, at B18.

${ }_{196}^{681}$ F.2d 1362 (11th Cir. 1982).

${ }^{197}$ See id. at 1364 .

${ }^{198}$ The district court ruled that the EMI program did not violate the First Amendment because the program had a secular purpose and a primary secular effect. Sé id. at 1365 .

${ }^{199}$ See id.

${ }^{200}$ Id. (citation omitted).

201827 F. Supp. 261 (S.D.N.Y. 1993).

${ }^{202}$ See id. at 262.

${ }^{203}$ See id. Drug and alcohol treatment programs are often required as a condition of probation to promote rehabilitation of the offender. See supra note 15 and accompanying text. 
attendance at $\mathrm{AA}$ meetings violated his right to free exercise of religion. As Warner argued, the AA program included "language acknowledging the existence of a Higher Power and the necessity of subjugating oneself to such a Power as a precondition to successful treatment of alcoholism." 204 Warner claimed to be an atheist. ${ }^{205}$ After the criminal court dismissed Warner's motion for mootness, ${ }^{206}$ he brought a $\S 1983^{207}$ claim on the grounds that his forced participation in AA violated the Establishment Clause of the U.S. Constitution. ${ }^{208}$

The district court held that Warner's complaint adequately alleged a violation of his constitutional rights. ${ }^{209}$ First, the court found that atheism falls within First Amendment protection because the "government may not compel affirmation of religious belief." 210 Second, the court held that the condition was obligatory, since Warner could have rejected the AA treatment for religious reasons, "but only at the potential cost of incarceration." 211 Finally, the court held that despite the fact that requiring AA attendance serves the secular purpose of rehabilitation, "AA arguably has a primary effect of advancing religion. ${ }^{n 12}$ These factors, along with the religious nature of $\mathrm{AA}$ and the vulnerability of the plaintiff, convinced the district court to deny the probation department's motion to dismiss Warner's complaint. ${ }^{213}$

While Owens and Warren demonstrate that some reviewing courts might closely analyze probation conditions that associate the probationer with an ideology, these kinds of probation conditions merit special attention for several reasons. Ideology-related conditions differ from other probation conditions in many ways that suggest that they are inappropriate to impose as a condition of probation. $^{214}$ As a result, the infrequency with which probation

204 Warner, 827 F. Supp. at 262.

205 See id. at 263.

${ }^{206}$ See id. Before the criminal court heard Warner's case, his probation officer provided him with several names of alcohol abuse counselors who could provide treatment without emphasis on God or spirituality. See id.

20742 U.S.C. § 1983 (1988).

${ }^{208}$ See Warner, 827 F. Supp. at 263.

${ }^{209}$ See id. at 266.

${ }^{210} I d$. at 265 (quoting Employment Div. v. Smith, 494 U.S. 872, 877 (1990)).

211 Id.

${ }^{212} \mathrm{Id}$. at 266.

${ }^{213}$ See id. at $266-68$ (discussing the vulnerability of the plaintiff to mandatory exposure to the religious indoctrination of AA principles).

${ }^{214}$ See infra notes 217-24 and accompanying text. 
conditions are appealed ${ }^{215}$ and the current confusion within the courts as to the proper standard to be applied ${ }^{216}$ significantly affect fundamental First Amendment rights and require that reviewing courts develop a clear standard to guide sentencing courts in the use of their discretion.

\section{B. Ideology-Related Conditions of Probation}

\section{How They Differ}

Conditions of probation that affirmatively require an offender to become associated with an ideology differ from other conditions of probation in several ways. Ideology-related conditions relate to the purposes of probation only indirectly, by attempting to reform the offender and to mold her into adopting certain qualities not necessary to be a productive member of society. Although education in the implications and effects of environmental laws serves the dual purposes of probation, rehabilitation and public safety, membership in or financial support of an environmental advocacy organization is unnecessary to the goals of probation. There are other ways in which to educate an offender about environmental issues and applicable laws. ${ }^{217}$

In contrast, prohibitive conditions of probation directly relate to the purposes of probation by removing the probationer from the circumstances that originally caused the criminal offense. For example, if the offense occurred during a political demonstration, a prohibition on active participation in public demonstrations will ensure that the probationer does not repeat the offense. ${ }^{218}$ Similarly, if the offense was an impropriety related to a union position, a prohibition on holding a union position or a position of authority within any organization that receives union funds ensures the probationer will be unable to repeat the offense. ${ }^{219}$ These

215 See supra note 55.

${ }^{216}$ See supra notes $105-71$ and accompanying text.

217 See infra notes 254-60 and accompanying text (discussing the importance for First Amendment purposes of an ideologically neutral vehicle of compelled speech).

${ }^{218}$ See, e.g., In re Mannino, 92 Cal. Rptr. 880, 886-89 (Ct. App. 1971) (upholding conditions of probation to the extent that they prohibited the probationer's active participation in demonstrations when the probationer's conviction arose out of a student demonstration that turned violent), overruled on other grounds, 851 P.2d 802 (Cal. 1993).

${ }^{219}$ See, e.g., United States v. Hughes, 964 F.2d 536, 542 (6th Cir. 1992) (noting that an effect of the prohibition will be to "rehabilitate [the probationer] by removing him 
probation conditions meet both goals of probation by promoting rehabilitation of the probationer and ensuring public safety.

Furthermore, the assertion that ideology-related conditions of probation serve the purposes of probation at all is tenuous at best. A requirement that an offender join a political advocacy group does nothing to further the public safety. ${ }^{220}$ In addition, it is unlikely that a contemptuous member of the Sierra Club will benefit from any educational aspects of membership. ${ }^{221}$

By contrast, affirmative conditions of probation that notify the public of the offense serve not only public protection and rehabilitation, but also other permissible purposes of probation. In the Clark case, for example, the harm committed by the officers to the police department was reputational. Requiring a public apology in this situation can be viewed as a form of restitution to the aggrieved party in that the apology will help to restore the police department to its pre-perjury reputation within the community. Such restitution is explicitly authorized by the Federal Probation Act, the SRA, and many state probation statutes. ${ }^{222}$ Similarly, public notice probation conditions serve rehabilitation by ensuring that the probationer will be removed from circumstances that caused the offense and by enlisting the public's help in this goal. ${ }^{223}$

from the environment that originally led to his criminal activity"), cert. denied, $113 \mathrm{~S}$. Ct. 1254 (1993); United States v. Tonry, 605 F.2d 144, 151 (5th Cir. 1979) (noting that probation conditions that prohibited a probationer, convicted of violating the Federal Election Campaign Act, from running for political office and from engaging in political activity "assure[] that the [probationer], while free to return to community life and earn his livelihood, will not be tempted to engage in illicit electoral activity during his probation, thus serving the purpose of protection").

${ }^{220}$ By itself such a condition of probation does not ensure public safety because it does not remove the probationer from the circumstances that originally led to the underlying violation. It is only in conjunction with other conditions of probation that public safety might be promoted. Indeed, all three cases that required membership in or contribution to an advocacy organization imposed additional conditions of probation that sought to protect the public from future criminality. See Ohio v. Bohnert, No. B91-2520 (C.P. Hamilton County, Ohio Nov. 6, 1991) (imposing additional probation conditions prohibiting the probationer from becoming involved in any waste disposal business and requiring the probationer to perform community service); Cruel and Unusual Punishment, supra note 7, at 9 (imposing additional probation conditions of home incarceration and community service); Hunting Guide Sentenced, supra note 7, at 5A (imposing additional probation condition prohibiting probationers from any hunting activity).

221 See Felsenthal, supra note 7, at B1, B2 (quoting a Sierra Club vice president as saying, "Realistically, these members [probationers compelled to join] aren't going to be active participants in our efforts' ... [since w] hat gets said at group meetings 'may go in one ear and out the other').

${ }_{222}^{22}$ See supra notes $38-42,64$ and accompanying text.

${ }^{223}$ See Filcik, supra note 38 , at 322-23 (noting that public signs not only inform 
Ideology-related probation conditions purport to rehabilitate the offender through education. The nature of this education, however, is not limited to an explanation of the laws or to suggestions at how to end an addiction; rather, the education extends beyond this proper boundary into the realm of moral education that imposes on constitutional rights. ${ }^{224}$ As discussed below, the Constitution protects the freedom from government imposition of ideology.

\section{Constitutional Aspects}

It is useful to examine the constitutional aspects of governmentcompelled association with, or support of, an ideology to analyze how such compulsion should be scrutinized when imposed as a condition of probation.

\section{a. Protected Speech Is Implicated}

Compelled association with, or support of, a political advocacy organization implicates fundamental rights protected by the First Amendment. In Wooley v. Maynard, ${ }^{225}$ the Supreme Court ruled that the "right of freedom of thought protected by the First Amendment ... includes both the right to speak freely and the right to refrain from speaking at all. ${ }^{226}$ This right to refrain from speaking stems from the First Amendment freedom to be "intellec-

the public of the probationer's status affording them the opportunity to assist in the defendant's rehabilitation," but also enable the public to "assist in monitoring a probationer's behavior by contacting authorities when necessary").

${ }^{224}$ See Owens v. Kelley, 681 F.2d 1362, 1365-66 (11th Cir. 1982). The Owens court recognized that "there is a fine line between rehabilitation efforts which encourage lawful conduct by an appeal to morality and the benefits of moral conduct to the life of the probationer, and efforts which encourage lawfulness through adherence to religious belief. Nevertheless, this is the line that must not be overstepped." Id.

${ }_{225}^{25} 430$ U.S. 705 (1977).

${ }^{226}$ Id. at 714. The Court earlier addressed this issue in the context of state efforts to implement an integrated bar association. See Lathrop v. Donohue, 367 U.S. 820 (1961). In Lathrop, however, a majority of the Court declined to address the First Amendment issue. See id. at 845 (" $[0] n$ this record we have no sound basis for deciding appellant's constitutional claim insofar as it rests on the assertion that his rights of free speech are violated .... . ). Justices Harlan, Frankfurter, Black, and Douglas, believed that the issue was properly raised in front of the Court. Justice Black, in a lengthy dissent, noted that "I can think of few plainer, more direct abridgments of the freedoms of the First Amendment than to compel persons to support candidates, parties, ideologies or causes that they are against." Id. at 873 (Black, J., dissenting). Similarly, Justice Douglas concluded that "the First Amendment applies strictures designed to keep our society from becoming moulded into patterns of conformity which satisfy the majority." Id. at 885 (Douglas, J., dissenting). 
tually and spiritually diverse or even contrary" that was recognized by the Court in West Virginia State Board of Education v. Barmette. ${ }^{227}$

The issue in Wooley was whether a state could constitutionally require a person to display on his private property an ideological message that he found repugnant. A New Hampshire statute mandated that noncommercial vehicles use license plates bearing the state motto, "Live Free or Die." ${ }^{228}$ Maynard objected to displaying the motto on his automobile since as a Jehovah's Witness he found the motto repugnant to his moral, religious, and political beliefs. Maynard was prosecuted for violation of the statute three times within two months. ${ }^{229}$ The Supreme Court found that the state invaded the "sphere of intellect" by requiring that an individual "be an instrument for fostering public adherence to an ideological point of view he finds unacceptable. ${ }^{n 230}$ The Court concluded that the "First Amendment protects the right of individuals to hold a point of view different from the majority and to refuse to foster ... an idea they find morally objectionable. ${ }^{n 231}$

Courts have further refined the theory of forced speech and association. The determination whether a state action compels speech or association is a question of fact. ${ }^{232}$ A review of the cases has led a federal court to conclude that First Amendment speech was commonly found in an "organization's advancement of positions affecting matters of public debate. ${ }^{233}$ In addition, the public's perception of the relationship between the compelled activity and the participant is important. ${ }^{234}$ For example, the

${ }^{227} 319$ U.S. 624, 641 (1943). The Court in Barnetle proceeded to note that "[i]f there is any fixed star in our constitutional constellation, it is that no official, high or petty, can prescribe what shall be orthodox in politics, nationalism, religion, or other matters of opinion or force citizens to confess by word or act their faith therein." Id. at 642 .

${ }^{228}$ See Wooley, 430 U.S. at 707.

229 See id. at 707-09.

${ }^{230} \mathrm{Id}$. at 715 .

${ }^{231}$ Id. One commentator has termed this right to be free from government compulsion to engage in speech or associational activities as a "negative right" and its protection as "negative protection." David B. Gaebler, First Amendment Protection Against Government Compelled Expression and Association, 23 B.C. L. REv. 995, 996 (1982).

${ }^{232}$ See, e.g., Steirer v. Bethlehem Area Sch. Dist., 987 F.2d 989, 995 (3d Cir.) (noting that to decide whether the compelled conduct is expressive, the court must look to "the nature of the activity in conjunction with the factual context and environment in which it is undertaken"), cert. denied, $114 \mathrm{~S}$. Ct. 85 (1993).

${ }^{235}$ Washington Legal Found. v. Massachusetts Bar Found., 795 F. Supp. 50, 55 (D. Mass. 1992), affd, 993 F.2d 962 (1st Cir. 1993).

${ }^{234}$ See Wooley, 430 U.S. 705, 717 n.15 (distinguishing the national motto "In God 
court in Steirer $v$. Bethlehem Area School District ${ }^{235}$ ruled that a community service requirement by a public high school did not compel speech because the plaintiffs failed to show that the public perceived that the students were expressing a belief in the value of altruism. ${ }^{236}$

Wooley and its progeny dictate that compelling a probationer to become a member of a political advocacy organization similarly breaches the promise of First Amendment protection. The Sierra $\mathrm{Club},{ }^{237}$ for example, is an organization dedicated to environmental preservation. ${ }^{238}$ It is probable that any person convicted of an environmental crime does not support the Sierra Club's political agenda. The compelled support of this ideology, whether most Americans agree with it or not, intrudes on the freedom to refuse to foster an ideology one finds objectionable. ${ }^{239}$

We Trust" that is on U.S. currency from the state license plate because currency is not really associated with the bearer, since it is "generally carried in a purse or pocket and need not be displayed to the public"); see also Norman L. Cantor, Forced Payments to Service Institutions and Constitutional Interests in Ideological Non-Association, 36 RUTGERS L. REV. 3, 15 (1983) (noting that "it is not as clear that there is forced ideological or political association in the absence of compelled payor identification" with the compelled expression); Gaebler, supra note 231, at 1010 ("Unless the government requires an individual to do something which reasonably identifies him with a message it is difficult to describe the government's actions as compelling expression."); cf. Washington Legal Found., 993 F.2d at 979 ("To affect First Amendment rights, there must be a connection between dissenters and the organization so that dissenters reasonably understand that they are supporting the message propagated by recipient organizations.").

${ }^{235} 987$ F.2d 989 (3d Cir.), cert. denied, 114 S. Ct. 85 (1993).

${ }^{296}$ See id. at 995 (noting the "significance.for First Amendment purposes of the viewer's perception"); $i d$. at 997 (stating that "plaintiffs have produced no evidence that people in the community who see these students performing community service are likely to perceive their actions as an intended expression of a particularized message of their belief in the value of community service and altruism").

${ }^{297}$ The Sierra Club will be used throughout the remainder of this Comment as an example of a political advocacy group to which a probationer might be compelled to join as a condition of probation.

${ }^{238}$ See Sierra Club, Financlal Report 2 (1993).

The Sierra Club ... is a[n] . . organization established to explore, enjoy and protect the wild places of the earth; to practice and promote the responsible use of the earth's ecosystems and resources; to educate and enlist humanity to protect and restore the quality of the natural and human environment; and to use all lawful means to carry out these objectives.

Id.

${ }^{239}$ See Wooley, 430 U.S. at 715 ("The fact that most individuals agree with the thrust of [the state] motto is not the test; most Americans also find the flag salute acceptable."); $c f$. Gaebler, supra note 231, at 1005 (noting that "[w]hether or not the individual agrees with the views he is required to express, and whether or not others perceive his coerced expression as sincere make no difference" to an individual's First 
Furthermore, the activities of the Sierra Club contribute greatly to matters of public debate. The public debate over environmental issues has increased tremendously over the last two decades. Both the federal and state governments spend a substantial amount of money implementing environmental laws and the courts are frequently engaged in battles that implicate environmental issues. Environmental issues arise as major issues in presidential campaigns $^{240}$ as well as in international trade agreements. ${ }^{241}$ The Sierra Club devotes its annual budget of over fifty million dollars to advancing one side of the environmental controversy through lobbying and advocacy. ${ }^{242}$ The Sierra Club also engages in extensive litigation in federal and state courts $^{243}$ and has an affiliated

Amendment interest in selfhood).

${ }^{240}$ See Casey Bukro, Ecologists Certain About Their Favorite, CHI. TRIB., Nov. 1, 1988, $\S$ News, at 11 ("The environment has emerged as an election issue in a year when planet Earth appeared to strike back against years of pollution abuses."); John B. Oakes, Bush vs. Bush on the Environment, N.Y. TIMES, Oct. 15, 1988, at 31 ("[T]he environmental question is as significant as any now facing the American voter, and more significant than most."); Keith Schneider, Clinton and Bush Show Contradictions in Balancing Jobs and Conservation, N.Y. TIMEs, Oct. 13, 1992, at A18 (discussing the candidates' environmental records and noting that Clinton's aides "say one of the big reasons for their candidate's lead in the national polls is his support for a Government that will take an active role in reshaping the nation's environmental and energy programs"); Michael Weisskopf, Rival Running Mates Clash on Shades of Green, WASH. POST, Aug. 8, 1992, at AI (calling the environment issue a "staple of presidential politics").

${ }^{241}$ For example, environmental concerns played a large role in the Clinton administration's negotiations and ultimate passage of the North American Free Trade Agreement ("NAFTA"). See Harold Gilliam, How Green Is NAFTA? Two Environmentalists-One Pro, One Con-Take on the Treaty, S.F. CHRON., Oct. 24, 1993, at 5/Z1 (outlining the debate over NAFTA's impact on the environment); Charlotte Grimes, Side Agreements Aimed at NAFTA Opponents, ST. LouIS POST-DISPATCH, Sept. 13, 1993, at $5 \mathrm{~B}$ (noting that President Clinton's "administration sought the . . . environmental side agreement[] in hope of defusing . . . arguments" that NAFTA would add to environmental problems along the U.S.-Mexican border); Gary Lee, At Border, NAFTA's Environmental Promise Is Murky, WASH. POST, Nov. 15, 1993, at A1, A8 (discussing the predicted environmental effects of NAFTA and the lobbying campaigns of many environmental groups).

${ }^{242}$ See SIERRA CLUB, supra note 192, at 6-9 (year-end financial statement, year ending December 31, 1991). The Sierra Club lobbies at the local, state, national, and international levels. See id. at 6 . Nearly $25 \%$ of the Club's budget was directed toward influencing public policy in fiscal year 1991. See id. at 11. A primary goal of the Club can be summed up with the following quote: "We offer to America and the world our vision of humanity living in harmony with nature. We dedicate ourselves to achieving this vision as we reaffirm our passionate commitment to explore, enjoy, and protect the Earth." Id. at 8.

${ }_{243}$ Most of the Sierra Club's litigation efforts are maintained by its legally independent affiliate, the Sierra Club Legal Defense Fund. See SIERRA Club, supra note 238 , at 3 . 
political action committee. ${ }^{244}$ Due to the highly visible and influential activities of the Sierra Club, forced membership in the organization certainly implicates compelled speech.

Finally, there is a likelihood that the public will perceive membership in the Sierra Club as an affirmation of the participant's support and belief. Unlike Steirer, in which all of the students in the public school system were required to perform community service as a precondition to high school graduation, the lone probationer who is compelled to become a member in good standing of the Sierra Club does not have the advantage of safety in numbers. The natural perception of one who attends Sierra Club meetings is that the person supports the organization and its goals. To correct this misperception, the probationer would have to reveal the true reasons for her recent membership and risk humiliation, being ostracized, or even harassed. Such harassment should not be the cost of exercising one's legitimate right to refuse to foster an ideology she finds objectionable. ${ }^{245}$

Even merely requiring a probationer to contribute money to a political advocacy organization implicates protected speech. While many authorities agree that a probationer can be required as a condition of probation to contribute money to a charitable organization, ${ }^{246}$ compelling contribution to a political advocacy organization crosses the line into protected speech. The Supreme Court has recognized that contributing to a political organization is a form of speech. In Buckley $v$. Valeo, ${ }^{247}$ the Court held that "[m]aking a contribution, like joining a political party, serves to

${ }^{244}$ The Sierra Club Political Committee supports the Club's belief that "commitment to environmental protection is an important qualification for those who seek public office." SIERRA CLUB, supra note 192, at 11.

${ }^{245}$ See Gaebler, supra note 231, at 1003-07 (arguing that although compelled speech does not preclude the opportunity to disavow the compelled expression, the necessity of disavowal deprives the individual of the right to remain silent and furthermore fails to remedy the loss of control over the projection of one's public identity).

${ }^{246}$ See United States v. Posner, 694 F. Supp. 881, 883, $887-89$ (S.D. Fla. 1988) (upholding a condition of probation that required defendant to contribute $\$ 3,000,000$ and 20 hours per week to formulate and implement a "meaningful plan dedicated to alleviating the problem of the homeless in South Florida"); People v. Burleigh, 727 P.2d 873, 874-75 (Colo. Ct. App. 1986) (upholding a condition of probation that defendant, who pleaded guilty to unlawful dispensing of a controlled substance, contribute $\$ 5000$ to a mental health center that conducted drug treatment programs); see also Howard, supra note 43 , at $541-44$ (discussing the propriety of requiring charitable contributions as a probation condition for corporate defendants).

247424 U.S. 1 (1975). 
affiliate a person" with the organization receiving the contribution. ${ }^{248}$ Further, a "contribution serves as a general expression of support." 249 As such, contributing to an organization for the purpose of spreading a political message is protected speech under the First Amendment.

Most importantly, freedom of expression through the contribution of money encompasses the right to be free from compelled contribution. In Abood v. Detroit Board of Education, ${ }^{250}$ the Court held that " $[t]$ he fact that the appellants are compelled to make, rather than prohibited from making, contributions for political purposes works no less an infringement of their constitutional rights." 251 Therefore, when a state authorizes an "agency shop" whereby every employee must pay a fee to the union equal to membership dues, regardless of whether the employee is a member, the union cannot use the money to support political issues beyond those related to its duties as bargaining representative of the employees. ${ }^{252}$ Similarly, if a probationer is required as a condition of probation to contribute money to a charitable organization, the state compels speech by ordering that the contribution be made to a political advocacy organization. ${ }^{253}$

\section{b. Compelled Speech Is Not Justified}

The government cannot compel speech unless the compulsion serves a compelling state interest. ${ }^{254}$ To support compelled speech, the compelling state interest must first be ideologically neutral. ${ }^{255}$ The Wooley court held that "where the State's interest is to disseminate an ideology, no matter how acceptable to some, such interest cannot outweigh an individual's First Amendment

${ }^{248} I d$. at 22. In Buckley, the recipients were groups supporting candidates for political office and individual candidates.

$249 \mathrm{Id}$. at 21.

${ }^{250} 431$ U.S. 209 (1977).

251 Id. at 234.

${ }^{252}$ See id. at 235-36.

${ }^{253}$ See also Washington Legal Found. v. Massachusetts Bar Found., 795 F. Supp. 50, 55 (D. Mass. 1992) ("In prohibiting coerced contributions to . . partisan issues, courts recognize that the First Amendment mandates that the interchange of information and ideas be free from compulsion." ), aff'd, $993 \mathrm{~F} .2 \mathrm{~d} 962$ (1st Cir. 1993).

254 See Wooley v. Maynard, 430 U.S. 705, 715-16 (1977); Gaebler, supra note 231, at 1016-17 (suggesting that courts balance the infringement of "negative" First Amendment rights against any governmental interest furthered by the compelled expression).

${ }^{255}$ See Wooley, 430 U.S. at 717. 
right to avoid becoming the courier for such message." 256 Secondly, Wooley requires that there be no more narrow manner in which the compelling state interest can be achieved. ${ }^{257}$ If there are less drastic means that achieve the same purpose, then compelling speech through forced membership or support is unconstitutional.

The state's interest in requiring membership or support of the Sierra Club as a condition of probation for someone convicted of an environmental crime is rehabilitative. The Sierra Club, however, is not an ideologically neutral vehicle for this rehabilitation. The Third Circuit in Galda v. Rutgers ${ }^{258}$ had to determine whether an organization supported by mandatory student fees at a public university was ideologically neutral. The court looked to the nature of the organization and its primary function in considering whether it maintained a sufficient educational component to outweigh the ideological component. ${ }^{259}$ The court found that the educational aspects of the group were only incidental to promotion of its political goals, and therefore, the state had not met its burden of showing a compelling state interest. ${ }^{260}$

Although the Sierra Club's agenda includes public education, the organization is a political advocacy group that has an interest in educating the public not only in environmental issues and laws, but toward a certain environmental philosophy. ${ }^{261}$ The history of the Sierra Club reveals that the group was born out of a desire for social change. ${ }^{262}$ Education is only an incidental aspect of the Sierra Club. Furthermore, any educational value of the organization will be lost on a probationer who is opposed to the Sierra Club's ideological aims.

${ }^{256} I d$.

${ }^{257}$ See id. at 716-17.

253772 F.2d 1060 (3d Cir. 1985), cert. denied, 475 U.S. 1065 (1986).

${ }^{259}$ See id. at 1065-66. It is interesting to note that the organization at issue in Galda was the New Jersey Public Interest Research Group, whose goals include environmental preservation. See id. at 1061 n.1.

${ }^{260} \mathrm{See}$ id. at 1065 (finding that the "educational benefits are only 'incidental'arising from or accompanying the principal objectives-and subordinate to the group's function of promoting its political and ideological aims").

${ }^{261}$ See supra notes $237-44$ and accompanying text.

${ }^{262}$ Change continues to be a focus in the Club's goals; thus, it engages in lobbying and litigation. See SIERrA CluB, supra note 192, at 3 ("We see fundamental changes.... That means ending the dominance of short sighted political and economic interests, and adopting national and global priorities, policies, and values aimed at leaving a healthy environment for future generations."). 
Finally, the state can satisfy its legitimate interest in rehabilitation with means that infringe less drastically on the constitutional right to be free from compelled speech and association. A person who has been convicted of an environmental crime would surely benefit from an education in the nature, scope, and implications of the environmental laws. Yet this education need not contain an ideological slant. Courses offered by legitimate charitable organizations $^{263}$ or public schools might fit this need. Because the state can achieve its legitimate and substantial interest in rehabilitation with a program that infringes less on fundamental constitutional rights, compelling a probationer to join or support a political advocacy organization should be unconstitutional under this traditional constitutional analysis. ${ }^{264}$

\section{Ideology-Related Probation Conditions Obstruct Meaningful Rehabilitation of the Probationer}

By unnecessarily infringing on the right to be free from compelled speech, ideology-related probation conditions impede full rehabilitation of the probationer. First Amendment protections provide the opportunity for individual self-fulfillment, autonomy, and human dignity. ${ }^{265}$ According to the social contract doctrine, society grants its members the guarantee of this freedom in exchange for the members' agreement to abide by society's legal rules. ${ }^{266}$ In a democracy where members of the community have

${ }^{263}$ For example, the Environmental Law Institute in Washington, D.C. provides such courses and is classified as a charitable organization under $\S 501$ (c)(3) of the Internal Revenue Code. See ENVIRONMENTAL LAW INST., ANNUAL REPORT 1992, at 33 (1993).

264 Whereas some courts considering the constitutionality of probation conditions have explicitly rejected the notion of applying a traditional constitutional analysis, see, e.g., United States v. Consuelo-Gonzalez, 521 F.2d 259, 265 n.14 (9th Cir. 1975), courts that have been presented with ideology-related probation conditions have adopted the traditional constitutional analysis, see Owens v. Kelley, 681 F.2d 1362, 1365 (11th Cir. 1982); Warner v. Orange County Dep't of Probation, 827 F. Supp. 261, 265-66 (S.D.N.Y. 1993).

${ }^{265}$ See Baker, supra note 30, at 992 (noting that "individual selffulfillment and participation in change are fundamental purposes of the first amendment $t^{\prime \prime}$ ); Richards, supra note 32 , at 68 (noting that "the value of free expression . . . rests . . . on deeper moral premises regarding the general exercise of autonomous expressive and judgmental capacity and the good that this affords in human life").

${ }^{266}$ Professor Baker explains the social contract doctrine as follows:

To justify legal obligation, the community must respect individuals as equal, rational and autonomous moral beings. For the community legitimately to expect individuals to respect collective decisions, i.e., legal rules, the 
a right to participate in the rulemaking process, everyone benefits from the exchange.

Conversely, when society breaches its contract promise of free expression, everyone is harmed. Imposition of a probation condition that compels expression robs the probationer of her selfrespect and integrity. ${ }^{267}$ Without these fundamental values, the probationer will be unable to become a healthy and productive member of society. ${ }^{268}$ And, without the foundation of self-respect and dignity, the probationer will be unable to respect, and will be unwilling to abide by, society's rules. As a result, the probationer's complete rehabilitation is obstructed and society is thereby harmed.

To fully encourage meaningful rehabilitation of the probationer, probation conditions must not coerce belief or expression. The sentencing court should not cross the line from permissible educational and rehabilitative efforts into coerced compliance with society's value system. ${ }^{269}$ Indeed, as noted earlier, ${ }^{270}$ rehabilitation begins with change within the offender. By guaranteeing the probationer the right to be free from compelled speech, the probationer is allowed to engage in the process of self-discovery, without which rehabilitation will remain incomplete. ${ }^{271}$

community must respect the dignity and equal worth of its members.

Baker, supra note 30 , at 991 .

${ }^{267}$ See id. at 992 (noting that "people's choices, their definition and development of themselves, must be respected-otherwise they become mere objects for manipulation or means for rationalizing someone else's ideals or desires"); id. at 1000 (noting that "respect for the integrity and autonomy of the individual usually requires giving each person at least veto power over the use of her own . . . speech"); Emerson, supra note 144, at 919 ("The attempt to coerce belief is not only one of the most destructive forms of restricting expression but it affords no substantial protection to any legitimate individual or social interest. It invades the innermost privacy of the individual and cuts off the right of expression at its source.").

${ }^{268}$ See Baker, supra note 30, at 996 ("Nevertheless, to the extent that speech is involuntary, is not chosen by the speaker, the speech act does not involve the selfrealization or the self-fulfillment of the speaker.").

${ }^{269}$ See ROTMAN, supra note 50, at 6 ("When the coercive methods of criminal law fail to force compliance to that minimum of morality that forms the core of the criminolegal systems, rehabilitation has to seek such compliance through a learning process, rather than by becoming a subtler and more intrusive form of coercion." ); id. at $118($ "The simple capacity to function in society without infringing its criminal law is a valid goal for rehabilitative endeavors, which is not necessarily equivalent to coerced compliance with society's value system."). It is important to note that many ideology-related probation conditions do not even coerce compliance with society's value system. Membership in the Sierra Club, for example, exposes a probationer to values of only a segment of society, which in fact through its lobbying and litigation efforts is trying to change society's values as reflected in the law. See supra note 262.

${ }^{270}$ See supra notes 100-04 and accompanying text.

${ }^{271}$ See ROTMAN, supra note 50 , at 8 (noting that for full rehabilitation, "[d]ialogue 


\section{Proposal for a Heightened Constitutional Scrutiny}

Affirmative conditions of probation that infringe on the constitutionally protected right to be free from compelled speech merit a heightened constitutional scrutiny. Imposed as a probation condition, the requirement of membership in a political advocacy organization implicates fundamental First Amendment rights that are insufficiently protected under either the reasonableness standard ${ }^{272}$ or the balancing standard. ${ }^{273}$

Assuming that an ideology-related condition of probation serves the purposes of rehabilitation, ${ }^{274}$ the reasonableness standard for determining to what extent a probationer should be accorded constitutional rights is inadequate to protect the right to be free from compelled speech. The reasonableness test scrutinizes the condition of probation in light of the offense, without any regard to the importance of the constitutional right involved. Because a sentence of Sierra Club membership is related to the offense of an environmental crime, the probation condition withstands review under the reasonableness test. When the constitutional right to be free from government-imposed ideology, a "fixed star in our constitutional constellation, ${ }^{275}$ is at risk, however, the gravity of the constitutional right must be considered.

The right to be free from compelled speech is also inadequately protected by the balancing standard. The balancing test requires a balancing between the government's interest in conditioning probation and the probationer's liberty interest. 'While this test might sometimes yield the proper protection for fundamental First Amendment rights, because its application is very fact-specific, it fails to guide sentencing courts in the use of their discretion. Furthermore, the balancing test fails to consider whether the state's interest in conditioning probation could be satisfied by less drastic means. Thus, under the balancing standard, courts can still impose restrictions on probationers that undermine our basic notions of democracy and selfhood ${ }^{276}$ and erect obstacles to full rehabilita-

is essential, not to issue authoritative statements but to encourage the process of selfdiscovery").

${ }^{272}$ See supra notes $118-31$ and accompanying text.

${ }^{273}$ See supra notes $132-48$ and accompanying text.

274 This, however, might not be the case. See supra notes 220-21 and accompanying text.

275 West Virginia Bd. of Educ. v. Barnette, 319 U.S. 624, 642 (1943).

${ }^{276}$ See supra notes 29-32 and accompanying text. 
tion. ${ }^{277}$

Ideology-related probation conditions merit special scrutiny for several reasons. First, they serve the goals of probation only indirectly. Second, the extent to which they affect rehabilitation is tenuous. ${ }^{278}$ Indeed, ideology-related probation conditions impede rehabilitation, because the probationer is denied the fundamental rights to self-respect and self-fulfillment, which are the basis of any rehabilitative efforts. Most important, ideology-related conditions of probation interfere with the "sphere of [the] intellect" 279 and unnecessarily intrude into realms that should be free from government interference in our society.

Therefore, conditions of probation that compel speech, expression, or association should be subjected to the least restrictive alternative standard. Such conditions of probation should pass constitutional scrutiny only if there is no more narrowly drawn infringement that equally satisfies a state's interests in rehabilitation and public safety. Under this standard, it is unlikely that any of the ideology-related probation conditions discussed above would withstand appellate review. For example, an offender could be equally, if not better, educated in environmental issues by mandatory attendance at an ideologically neutral education program. ${ }^{280}$ Similarly, an offender convicted of driving under the influence can undergo alcoholism counseling that does not contain religious components. ${ }^{281}$

Some critics of the least restrictive alternative standard allege that this standard provides probationers the same level of constitutional protection as nonprobationers. ${ }^{282}$ Where fundamental constitutional rights are concerned, however, an infringement should be allowed only when necessary to meet a compelling state interest. Indeed, the probationer is not off "scot-free": probation conditions properly impose on the probationer a veritable laundry

277 See supra notes $265-71$ and accompanying text.

${ }^{278}$ See supra notes $220-21$ and accompanying text.

${ }^{279}$ Wooley v. Maynard, 430 U.S. 705, 706 (1977).

${ }^{280}$ See supra notes $254-60$ and accompanying text.

${ }^{281}$ See Warner v. Orange County Dep't of Probation, 827 F. Supp. 261, 263 (S.D.N.Y. 1993) (noting that there are alcohol abuse counselors acceptable to an atheist); Christopher K. Smith, Note, State Compelled Spiritual Revelation: The First Amendment and Alcoholics Anonymous as a Condition of Drunk Driving Probation, 1 WM. \& MARY BILL RTS. J. 299, 316 (1992) (noting that "[i]t would be possible for judges or probation officers to create alternatives for those who reasonably object" to the religious component of $\mathrm{AA}$ as a condition of probation).

${ }^{282}$ See Bartrum, supra note 73, at 1045. 
list of duties and responsibilities. ${ }^{283}$ Finally, the state's compelling interests in rehabilitation and public safety adequately ensure a distinction between permissible infringements of constitutional rights of probationers and permissible infringements of constitutional rights of nonprobationers.

Ideology-related probation conditions aim to promote the rehabilitation or reformation of the probationer through education. Because education often encompasses ideological components, however, these conditions should be scrutinized by the highest constitutional standard. As shown by our expansive and successful public education system, this country can educate its population without indoctrinating it. Indeed, the best education infers the existence of and encouragement of an ideological plurality.

\section{CONCLUSION}

Creative sentencing is a necessary component of the criminal justice system in the latter part of Twentieth Century America. Prison overcrowding and geometrically increasing public deficits require that the judiciary be allowed to formulate alternatives to traditional incarceration, particularly where there is little danger to the community in doing so. Because trial judges are most familiar with the facts of each case, they should maintain broad discretion in determining conditions of probation.

An ideology-related condition of probation should be imposed, however, only when the least restrictive alternative standard has been satisfied. Application of this standard will reveal most ideology-related probation conditions as unnecessarily restrictive. Because of the unique nature of these probation conditions, the importance for rehabilitation that the probationer learn to live within societal norms, and the unique role of the right to be free from government-compelled ideology, ideology-related probation conditions merit this heightened constitutional scrutiny. After all, "the strength of a constitutional system lies in the protection it affords those who have trespassed." 284

${ }^{283}$ Examples of such duties include paying a fine, performing community service, maintaining gainful employment, supporting legal dependents, participating in alcohol or drug treatment, and submitting to regular unwarranted searches. See supra notes $15,41-42,64$ and accompanying text.

${ }^{284}$ Hink, supra note 35 , at 485 . 